Article

\title{
Seasonal Variations in Water Uptake Patterns of Winter Wheat under Different Irrigation and Fertilization Treatments
}

\author{
Ying Ma * and Xianfang Song \\ Key Laboratory of Water Cycle and Related Land Surface Processes, Institute of Geographic Sciences and \\ Natural Resources Research, Chinese Academy of Sciences, Beijing 100101, China; songxf@igsnrr.ac.cn \\ * Correspondence: maying@igsnrr.ac.cn; Tel.: +86-10-64889367
}

Received: 12 September 2018; Accepted: 8 November 2018; Published: 12 November 2018

\begin{abstract}
Irrigation and fertilization both affect the water cycle in agricultural ecosystems. It is difficult to quantify root water uptake (RWU) which varies with crop development and seasons. In this study, a Bayesian mixing model (MixSIAR) coupling with dual stable isotopes ( $D$ and ${ }^{18} \mathrm{O}$ ) was used to quantify RWU patterns for winter wheat under different irrigation and fertilization treatments between 2014 and 2015 in Beijing, China. The main RWU depth during the greening-jointing, jointing-heading, heading-filling, and filling-harvest stages was $0-20 \mathrm{~cm}, 20-70 \mathrm{~cm}, 0-20 \mathrm{~cm}$, and $20-70 \mathrm{~cm}$, respectively, which showed water uptake proportions of $67.0 \%, 42.0 \%, 38.7 \%$, and 34.9\%, respectively. Significant differences in RWU patterns appeared between the 2014 and 2015 seasons. The main RWU depth increased gradually from $0-20 \mathrm{~cm}$ at the greening-jointing stage to $20-70 \mathrm{~cm}$ at the jointing-heading stage and 70-150 cm during the heading to harvest period in 2014 . However, winter wheat primarily took up soil water from the $0-70 \mathrm{~cm}$ layer in 2015 . The average water uptake proportion in the top layer $(0-20 \mathrm{~cm})$ in $2015(42.6 \%)$ was remarkably higher than that in $2014(28.7 \%)$. There was a significantly negative relationship $(p<0.01)$ between the water uptake proportion and the proportion of root length at the filling-harvest stage in 2014, while no significant correlation $(p>0.05)$ was found in 2015. Variable distributions of root characteristics and soil moisture induced by different irrigation and fertilization comprehensively affected the RWU profile, particularly under severe drought environments in 2015. Treatments with fertilization of $105 \mathrm{~kg} \mathrm{hm}^{-2} \mathrm{~N}$ or irrigation of $20 \mathrm{~mm}$ during the greening-jointing stage significantly promoted water uptake contribution in the $70-150 \mathrm{~cm}(32.2 \%)$ and $150-200 \mathrm{~cm}(23.5 \%)$ layers at the jointing-heading stage in 2015, while other treatments had a shallow dominant RWU depth $(0-20 \mathrm{~cm})$. The planned wetting layer should be kept within the main RWU depth of $0-70 \mathrm{~cm}$ for improving irrigation water use efficiency.
\end{abstract}

Keywords: root water uptake; dual stable isotopes; MixSIAR model; irrigation and fertilization treatments; winter wheat

\section{Introduction}

Root water uptake (RWU) is a key process in the global water cycle [1]. More than $50 \%$ of total terrestrial evapotranspiration (ET) recycles to the atmosphere via plant roots [2]. The RWU is principally driven by transpiration flux and it is important to partition evapotranspiration into plant transpiration (T) and soil evaporation (E) for saving water in agricultural ecosystems [3,4]. The RWU varies with different irrigation and fertilization practices and it provides insights into the planning wetting soil layer for irrigated crops [5,6]. Despite its substantial importance, quantification of RWU still remains difficult due to limited technology to accurately quantify root water uptake, as well as the spatial and temporal variability of the uptake process [7]. 
Since RWU generally does not lead to isotopic fractionation or the magnitude of fractionation is too low to be observable for the majority of plant species, stable isotopic analysis is a powerful and valuable tool to identify and quantify RWU via the measurements of $\delta \mathrm{D}$ and $\delta^{18} \mathrm{O}$ abundance in waters [7,8]. Widely used methods to determine RWU patterns include the IsoSource [9] and Bayesian mixing models (e.g., SIAR [10], MixSIR [11], and MixSIAR [12]). In comparison, the Bayesian mixing models are particularly efficient in the case of multiple layers for illustrating the interest of reaching the best vertical resolution and maximizing the number of identified potential sources [7]. The MixSIAR model incorporates advances in MixSIR and SIAR that considers multiple sources of uncertainty and provides potential proportions of source contributions [12]. The MixSIAR model has been employed successfully to determine the contributions of soil water at different layers to the water uptake of field crops and natural plants [13-15].

Using water stable isotopes to determine plant water sources has gained significantly more attention in relation to forest, grass, and shrub ecosystems in the past three decades [16-18]. Only 15\% of previous studies tracked RWU in agricultural systems (e.g., maize, wheat, millet, rice, and alpine crops) [7]. The RWU varied in space (along the soil profile) and time (among different crop growth stages and seasons). Water stable isotopes were used to determine the main water uptake depth and proportional contribution of soil water to maize or wheat at different growth stages in a single growing season $[3,14,19,20]$. However, the distinct atmosphere evaporative demand and precipitation distribution in different seasons caused significant variability in water availability for crop water use $[6,13]$. Furthermore, previous studies were usually performed to quantify RWU under conventional irrigation and rain-fed conditions. Crops mainly took up water from shallow soil layers $(0-50 \mathrm{~cm})$ and a large proportion of irrigation and rainwater could not be utilized and percolated into deep layers under traditional irrigation depth $(100 \mathrm{~cm})$ in normal years [3,14,20]. Nevertheless, deep soil water contribution increased significantly under drought stress condition [6]. Therefore, the seasonal variation in RWU under different irrigation scenarios needs further quantification. This could help to optimize the planned wetting soil layer and improve water-saving practices.

The distribution of RWU in the soil profile depends on the presence of roots and their ability to extract water. The water stable isotopic technique provides a unique way to tackle the difficulty of disentangling actual RWU profiles with root characteristics [7]. In general, water uptake proportions are positively correlated with root length or dry root weight density for crops (summer maize, rice, and winter wheat) $[6,13,20]$. Nevertheless, a negative relationship was found between the RWU rate and root length for wheat grown in compacted soils [21]. RWU distribution was in agreement with root distribution, when plants did not extract water from soil layers with low root length densities in non- or less-water limited conditions (known as RWU compensation) [5,7]. In a drought-stress environment, the RWU profile was affected comprehensively by the root's ability to absorb water, soil water availability, and the difference in water potential between soil and root [22,23]. Different scenarios of water (irrigation and precipitation) and fertilization supply significantly changed root distribution and seasonal RWU patterns [4,24]. Understanding how the distribution of the root system and soil water affects the RWU depth and quantifying the magnitude of influence are crucial for the water management of irrigated crops [25].

In this study, the Bayesian mixing model (MixSIAR), in conjunction with $\mathrm{D}$ and ${ }^{18} \mathrm{O}$ dual stable isotopes, was utilized to identify RWU sources of winter wheat under different irrigation and fertilization treatments between 2014 and 2015 in Beijing, China. The three primary objectives of this study were to (1) quantify the water uptake proportions in different soil horizons at each growth stage, (2) compare seasonal variations in RWU patterns among different irrigation and fertilization treatments, and (3) evaluate the relationships between RWU patterns and root distribution and soil moisture depletion. The results were used to determine the planned wetting soil layer and provide insights into agricultural water management. 


\section{Materials and Methods}

\subsection{Field Experiments and Measurements}

Field experiments with winter wheat were conducted in plots from 2013 to 2015 at the Irrigation Experiment Station of the China Institute of Water Resources and Hydropower Research (IWHR) at Daxing, Beijing ( $39^{\circ} 37^{\prime} \mathrm{N}$ latitude, $116^{\circ} 26^{\prime} \mathrm{E}$ longitude, $40.1 \mathrm{~m}$ a.s.l. elevation) (Figure $\left.1 \mathrm{a}\right)$. The climate in this area is subhumid with a mean annual precipitation of $540 \mathrm{~mm}$ and a mean annual temperature of $12.1{ }^{\circ} \mathrm{C}$ [26]. However, precipitation during the winter wheat season only accounts for 20 to $30 \%$ of the annual precipitation, which is far less than the mean seasonal reference evapotranspiration $\left(\mathrm{ET}_{0}\right)$ $(610 \mathrm{~mm})$. As winter wheat has an average maximum rooting depth of $2 \mathrm{~m}$, soils were sampled every $20 \mathrm{~cm}$ in the 2-m profile, and adjacent layers with similar soil particle size and organic carbon content were merged into one layer. The profile was divided into four layers, and the main soil physical and chemical properties of each layer are shown in Table 1.
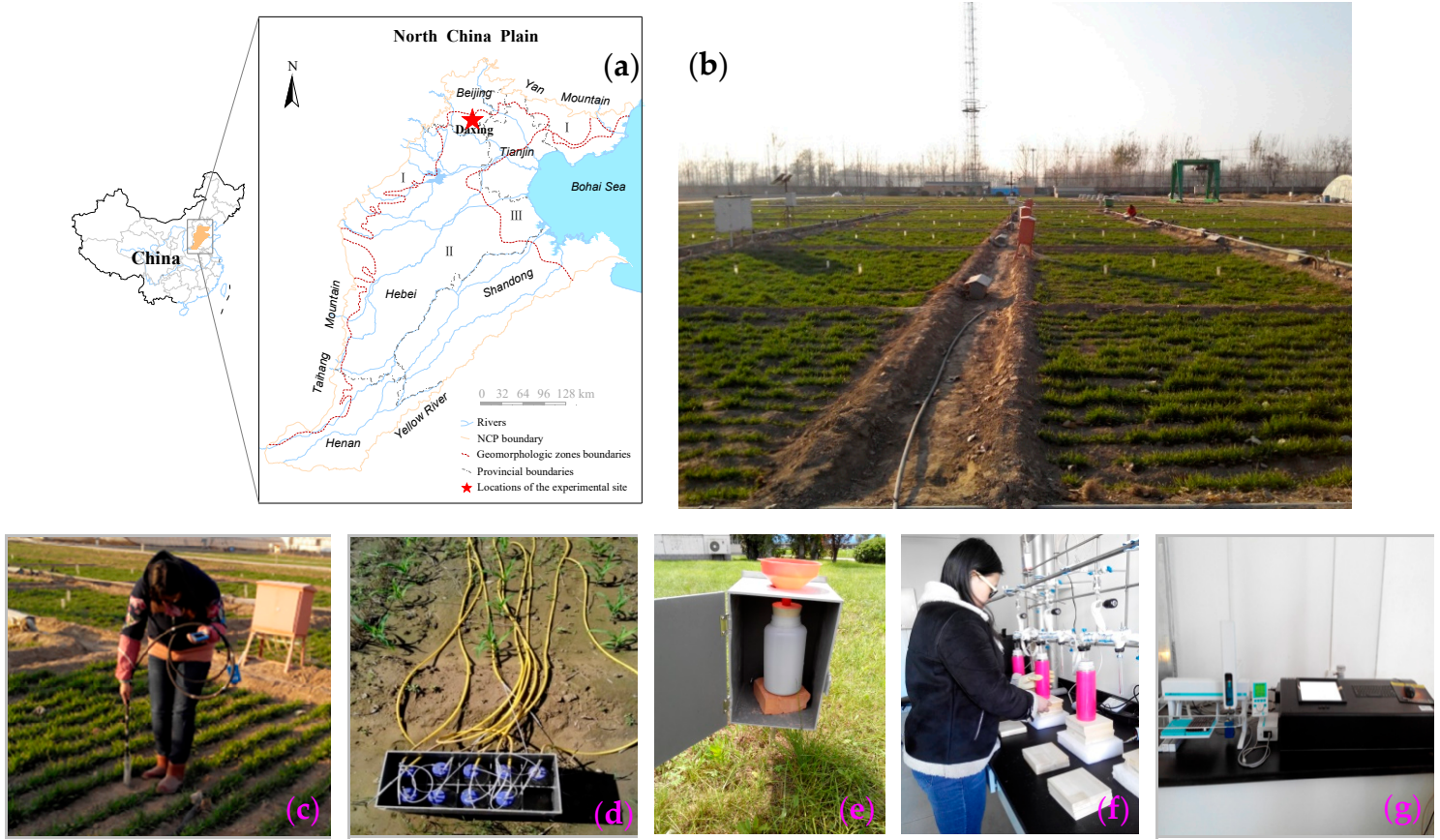

Figure 1. Schematic for the (a) location of the experimental site, (b) experimental plots, (c) soil water content measurement, collection of (d) soil water and (e) precipitation samples, (f) water extraction from soil and stem samples, and (g) isotopic analysis via the LGR.

Table 1. Physical and chemical properties of the soil profile at the experimental site.

\begin{tabular}{|c|c|c|c|c|c|c|c|c|c|c|c|c|}
\hline \multirow{2}{*}{$\begin{array}{c}\text { Depth } \\
\text { (cm) }\end{array}$} & \multicolumn{3}{|c|}{ Particle Size (\%) } & \multirow{2}{*}{$\begin{array}{c}\text { Soil } \\
\text { Texture }\end{array}$} & \multirow{2}{*}{$\begin{array}{c}\text { Bulk } \\
\text { Density } \\
\left(\mathrm{g} / \mathrm{cm}^{3}\right)\end{array}$} & \multirow{2}{*}{$\begin{array}{c}\theta_{\mathrm{s}} \\
\left(\mathrm{cm}^{3} / \mathrm{cm}^{3}\right)\end{array}$} & \multirow{2}{*}{$\begin{array}{c}K_{\mathrm{s}} \\
(\mathrm{cm} / \mathrm{d})\end{array}$} & \multirow{2}{*}{$\begin{array}{c}\text { OC } \\
(\mathrm{g} / \mathrm{kg})\end{array}$} & \multirow{2}{*}{$\begin{array}{c}\mathrm{EC} \\
(\mu \mathrm{S} / \mathrm{cm})\end{array}$} & \multirow{2}{*}{$\mathrm{pH}$} & \multirow{2}{*}{$\begin{array}{r}\mathrm{NH}_{4}{ }^{+}-\mathrm{N} \\
(\mathrm{mg} / \mathrm{kg})\end{array}$} & \multirow{2}{*}{$\begin{array}{r}\mathrm{NO}_{3}{ }^{-}-\mathrm{N} \\
(\mathrm{mg} / \mathrm{kg})\end{array}$} \\
\hline & Sand & Silt & Clay & & & & & & & & & \\
\hline $0-20$ & 58.8 & 33.2 & 8.0 & $\begin{array}{l}\text { Sandy } \\
\text { loam }\end{array}$ & 1.56 & 0.41 & 8.41 & 8.03 & 111.70 & 8.15 & 7.0 & 98.9 \\
\hline 20-120 & 65.3 & 26.7 & 8.0 & $\begin{array}{l}\text { Sandy } \\
\text { loam }\end{array}$ & 1.48 & 0.42 & 10.04 & 3.87 & 109.12 & 8.61 & 5.9 & 17.9 \\
\hline $120-180$ & 68.2 & 29.2 & 2.7 & $\begin{array}{l}\text { Sandy } \\
\text { loam }\end{array}$ & 1.45 & 0.45 & 7.45 & 1.52 & 87.60 & 8.66 & 6.3 & 20.2 \\
\hline $180-200$ & 32.0 & 51.0 & 17.0 & $\begin{array}{c}\text { Silt } \\
\text { loam }\end{array}$ & 1.25 & 0.51 & 0.66 & 5.41 & 161.80 & 8.27 & 4.4 & 19.0 \\
\hline
\end{tabular}

Note: OC: Organic $C ; \theta_{\mathrm{s}}$ : Saturated water content, $K_{\mathrm{s}}$ : Saturated hydraulic conductivity, EC: Electric conductivity, $\mathrm{pH}$ : Potential of hydrogen, $\mathrm{NH}_{4}{ }^{+}-\mathrm{N}$ : Ammonia nitrogen, $\mathrm{NO}_{3}{ }^{-}-\mathrm{N}$ : Nitrate nitrogen.

The sowing and harvest dates for winter wheat (variety: Zhongmai-175) were 9 October 2013 and 8 June 2014 in the 2014 growing season, respectively, and were 11 October 2014 and 8 June 2015 in the 
2015 growing season. Five irrigation and fertilization treatments (T1, T2, T3, T4, and T5) were applied during winter greening to the harvest season, and treatment T5 was set as the conventional agricultural management practices used by local farmers with total irrigation of $240 \mathrm{~mm}$ and nitrogen supply of $210 \mathrm{~kg} \mathrm{ha}^{-1} \mathrm{~N}$ (as urea) (Table 2). The irrigation and fertilization schedules were designed according to previous experimental data and literature in the NCP $[5,27,28]$. The referencing irrigation amount per time was approximately $80 \mathrm{~mm}$ in the study area [28]. The timing of irrigation primarily matched the key development stages of wheat. If only one round of irrigation was applied, the application date was recommended to be at the jointing-heading or heading-filling stage such as the T1 and T2 treatments [5,28]. Twice irrigation at the greening-jointing and filling-harvest stages (such as treatments T3 and T4) was beneficial for improving grain yield in a dry year [5]. Since fertilization is another critical factor to improve grain yield, two fertilization levels were designed as 0.5-fold (T1 and T3) and 1.5-fold (T2 and T4) the conventional nitrogen application rate. Three replicates were conducted for every treatment in the plots with an area of $6 \mathrm{~m} \times 5 \mathrm{~m}$ (Figure 1b). Basin irrigation with groundwater was implemented for all of the treatments. Precision-leveled basins were used to prevent runoff. Every irrigation event was provided in a single application per stage. The irrigation application dates were 27 March, 22 April, and 22 May in 2014 and 29 March, 9 May, and 21 May in 2015. Fertilizer was applied once on the same day for the first irrigation in each growing season.

Volumetric soil water content was observed at a $20-\mathrm{cm}$ interval in the $2-\mathrm{m}$ profile in each plot via a TRIME-IPH probe (IMKO GmbH, Ettlingen, German) (Figure 1c). The measurements were conducted every 5 to 7 days as well as before and after each irrigation or heavy rainfall events. Roots were sampled every $10 \mathrm{~cm}$ at the filling-harvest stage using a soil auger $(9.5 \mathrm{~cm}$ diameter $)$ and the soil was removed manually in washing cans. Root length was analyzed by the WinRHIZO system (Regent Instruments, QC, Canada). Winter wheat was harvested manually and air-dried to measure the crop yield for each plot.

Meteorological data were recorded every $30 \mathrm{~min}$ by the automatic weather station (Monitor Sensors, Caboolture, QLD, Australia). Temporal variations in the main climate parameters were shown in Figure 2. The mean temperature, mean relative humidity, rainfall amounts, and $\mathrm{ET}_{0}$ were $17.9^{\circ} \mathrm{C}$, $51.8 \%, 77.0 \mathrm{~mm}$, and $278.7 \mathrm{~mm}$ during the greening to harvest period in the 2014 season, and they were $17.3{ }^{\circ} \mathrm{C}, 47.8 \%, 74.7 \mathrm{~mm}$, and $300.6 \mathrm{~mm}$ in the 2015 season. Although both 2014 and 2015 seasons were dry with similar amounts of total precipitation, the precipitation and mean relative humidity at the jointing-heading stage in 2015 was $22.6 \mathrm{~mm}$ and $11.3 \%$ less than that in 2014, respectively. Higher temperature with an average increase of $2.1^{\circ} \mathrm{C}$ additionally intensified the dry climate condition at the jointing-heading stage in 2015. The $\mathrm{ET}_{0}$ increased by $26.9 \mathrm{~mm}$ at this stage in 2015 with respect to that in 2014. 
Table 2. Irrigation and fertilization (as urea) schedules for each treatment of the winter wheat during the experimental seasons.

\begin{tabular}{|c|c|c|c|c|c|c|c|c|c|c|c|}
\hline \multirow[b]{2}{*}{ Season } & \multirow[b]{2}{*}{ Treatment } & \multicolumn{2}{|c|}{ Greening-Jointing } & \multicolumn{2}{|c|}{ Jointing-Heading } & \multicolumn{2}{|c|}{ Heading-Filling } & \multicolumn{2}{|c|}{ Filling-Harvest } & \multicolumn{2}{|c|}{ Total } \\
\hline & & $\begin{array}{l}\text { Irrigation } \\
\text { (mm) }\end{array}$ & $\begin{array}{c}\text { Fertilization } \\
\text { (kg/ha N) }\end{array}$ & $\begin{array}{l}\text { Irrigation } \\
\text { (mm) }\end{array}$ & $\begin{array}{c}\text { Fertilization } \\
(\mathrm{kg} / \mathrm{ha} \mathrm{N})\end{array}$ & $\begin{array}{l}\text { Irrigation } \\
(\mathrm{mm})\end{array}$ & $\begin{array}{c}\text { Fertilization } \\
\text { (kg/ha N) }\end{array}$ & $\begin{array}{l}\text { Irrigation } \\
(\mathrm{mm})\end{array}$ & $\begin{array}{c}\text { Fertilization } \\
\text { (kg/ha N) }\end{array}$ & $\begin{array}{l}\text { Irrigation } \\
\text { (mm) }\end{array}$ & $\begin{array}{c}\text { Fertilization } \\
\text { (kg/ha N) }\end{array}$ \\
\hline \multirow{5}{*}{2014} & $\mathrm{~T} 1$ & 20 & 105 & 80 & - & - & - & - & - & 100 & 105 \\
\hline & $\mathrm{T} 2$ & 20 & 315 & 80 & - & - & - & - & - & 100 & 315 \\
\hline & T3 & 80 & 105 & - & - & - & - & 80 & - & 160 & 105 \\
\hline & $\mathrm{T} 4$ & 80 & 315 & - & - & - & - & 80 & - & 160 & 315 \\
\hline & $\mathrm{T} 5$ & 80 & 210 & 80 & - & - & - & 80 & - & 240 & 210 \\
\hline \multirow{5}{*}{2015} & $\mathrm{~T} 1$ & 20 & 105 & - & - & 80 & - & - & - & 100 & 105 \\
\hline & $\mathrm{T} 2$ & 20 & 315 & - & - & 80 & - & - & - & 100 & 315 \\
\hline & T3 & 80 & 105 & - & - & - & - & 80 & - & 160 & 105 \\
\hline & $\mathrm{T} 4$ & 80 & 315 & - & - & - & - & 80 & - & 160 & 315 \\
\hline & T5 & 80 & 210 & - & - & 80 & - & 80 & - & 240 & 210 \\
\hline
\end{tabular}

Note: The T5 treatment represents conventional practice, and “-" shows no irrigation or fertilization applied. 


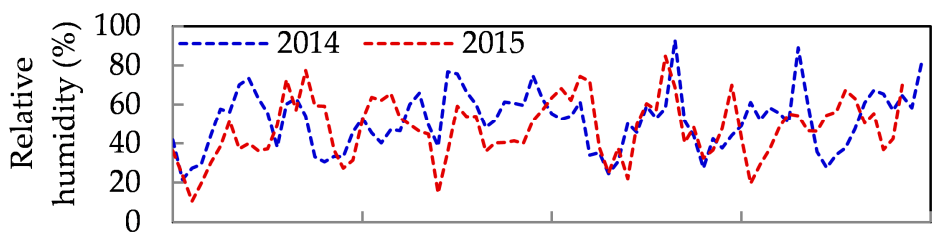

(a)

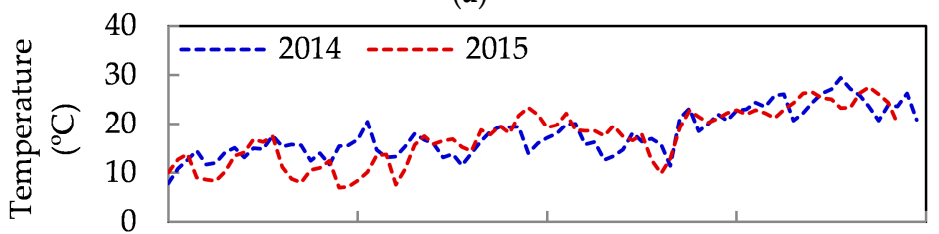

(b)

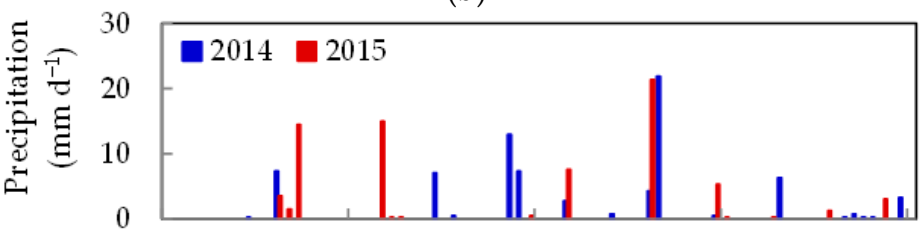

(c)

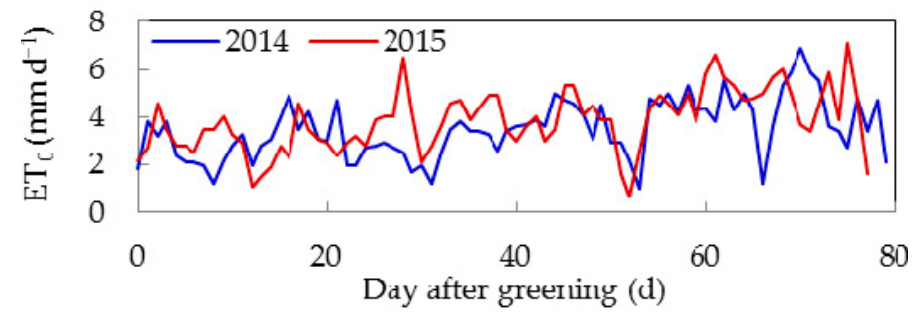

(d)

Figure 2. Temporal variation of (a) mean air temperature, (b) relative humidity, (c) precipitation, and (d) reference evapotranspiration $\left(\mathrm{ET}_{0}\right)$ throughout greening to harvest growing season for winter wheat in 2014 and 2015.

\subsection{Water Sample Collections and Isotope Analyses}

Water samples were collected to measure the ${ }^{18} \mathrm{O}$ and $\mathrm{D}$ isotopes in precipitation, irrigation, soil water, and stem water during greening to harvest period of winter wheat. Precipitation was collected in each rainfall event via a rain collector composed of a polyethylene bottle and funnel (Figure 1e). Evaporation during the rainfall process was prevented by placing a ping-pong ball at the funnel mouth [29]. Irrigation water in each irrigation event was sampled using a 50-mL polyethylene bottle and sealed with parafilm.

Three plants were sampled approximately once a week for each treatment. There were two or three times of sampling events during each growth period. The stem between the soil surface and the first node of each plant was collected for isotopic analysis. It was then cut into pieces of 2 to 3 $\mathrm{cm}$ in length, removing all the epidermises, and then stored in a vial [30]. Soil water at depths of 10, $20,30,50,70,90,110,150$, and $200 \mathrm{~cm}$ was sampled using a suction lysimeter made of a Teflon pipe and porous ceramic cup [29] (Figure 1d). The sampling dates were the same as those for stem water collection, and after each irrigation or heavy rainfall event. Additional soil samples were collected via a hand auger when the soil water content was close to the wilting point.

All the stem and soil samples were stored in a refrigerator $\left(-15^{\circ} \mathrm{C}\right.$ and $\left.-20^{\circ} \mathrm{C}\right)$ before isotopic measurements. Water in stem and soil samples were extracted by the cryogenic vacuum distillation system (LI-2000, LICA, Beijing, China) (Figure 1f). The Los Gatos Research (LGR) DLT-100 liquid water isotope analyzer (Mountain View, CA, USA) was used to measure the isotope composition of ${ }^{18} \mathrm{O}$ and $\mathrm{D}$ in different waters (Figure $1 \mathrm{~g}$ ). The measured ratios of ${ }^{2} \mathrm{H} /{ }^{1} \mathrm{H}$ and ${ }^{18} \mathrm{O} /{ }^{16} \mathrm{O}$ were calibrated against 
the VSMOW international standards and then converted to $\delta \mathrm{D}$ and $\delta^{18} \mathrm{O}$ values. The precision for $\delta \mathrm{D}$ and $\delta^{18} \mathrm{O}$ measurements was $\pm 1 \%$ and $\pm 0.1 \%$, respectively.

\subsection{Direct Inference Method and MixSIAR Model}

Since the groundwater level (mean of $16 \mathrm{~m}$ ) was beyond root water extraction depth, it could be supposed that winter wheat mainly utilized soil water at different depths (a mixture of precipitation, irrigation, and old soil water) in the study area. We used the direct inference method coupled with dual water stable isotopes to detect the potential water uptake depth of winter wheat [30]. The principle of this approach was to observe the depth at which the $\delta \mathrm{D}$ and $\delta^{18} \mathrm{O}$ values of soil water matched those of the stem water [30].

We used the MixSIAR model (v2.1.3) incorporating with $\delta \mathrm{D}$ and $\delta^{18} \mathrm{O}$ values to quantify the proportional contributions of soil water to winter wheat and determine the primary water uptake sources. Bayesian mixing models improved isotope analysis by explicitly accounting for uncertainty in source values, categorical and/or continuous covariates, and prior information. MixSIAR incorporated several advances in the Bayesian mixing model theory and included the features of source fitting (both for raw source data and means + SD data), error structure options (residual, combined source, or both), and optional individual effects, etc. [12].

Taking the vertical distributions of soil water isotopic compositions, soil water contents, and root lengths into consideration, the 2-m soil profile was divided into four layers as 0-20, 20-70, 70-150 cm, and $150-200 \mathrm{~cm}$. The $\delta \mathrm{D}$ and $\delta^{18} \mathrm{O}$ values for each layer were obtained by averaging those at all sampling depths within the corresponding layer. The $\delta \mathrm{D}$ and $\delta^{18} \mathrm{O}$ in soil water in each layer (raw source data) together with those in stem water (mixture data) were input to the MixSIAR model to quantify the proportional soil water contributions and determine the main water uptake sources of winter wheat. The probability density functions of variables were estimated based on the Markov chain Monte Carlo (MCMC) method in the MixSIAR model. The MCMC parameter run length was selected as "very long" for convergence. The model erroneous was evaluated via the SIAR (process and residual). The calculated $50 \%$ percentile of the posterior contribution was referred to the main proportional contribution of each source to winter wheat in this study.

\section{Results}

\subsection{Seasonal Variations in Soil Moisture Distribution}

Figure 3 shows the seasonal variations in the soil moisture under different treatments during 2014 and 2015 growing seasons. The mean values of initial soil water content for all treatments (with SD value) were $0.20(0.02), 0.26(0.03), 0.31(0.01)$, and $0.42(0.02) \mathrm{cm}^{3} \mathrm{~cm}^{-3}$ in the $0-20 \mathrm{~cm}, 20-70 \mathrm{~cm}$, $70-150 \mathrm{~cm}$, and 150-200 cm layers in the 2014 season, respectively, and $0.20(0.02), 0.26(0.02), 0.28(0.01)$, and $0.41(0.02) \mathrm{cm}^{3} \mathrm{~cm}^{-3}$ corresponding to the above layers in the 2015 season. Only small differences of the initial soil moisture occurred in the deep layers $(70-150 \mathrm{~cm}$ and $150-200 \mathrm{~cm}$ ) between the two growing seasons. Soil water content ranged from 0.08 to $0.33 \mathrm{~cm}^{3} \mathrm{~cm}^{-3}$ and varied significantly in shallow layers $(0-70 \mathrm{~cm})$ over wheat greening to harvest season. The mean soil water content was $0.29 \mathrm{~cm}^{3} \mathrm{~cm}^{-3}$ with SD of $0.03 \mathrm{~cm}^{3} \mathrm{~cm}^{-3}$ in the $70-150 \mathrm{~cm}$ layer. No significant change in soil water content appeared within the 150-200 $\mathrm{cm}$ layer (mean of $0.38 \mathrm{~cm}^{3} \mathrm{~cm}^{-3}$ with SD of $0.03 \mathrm{~cm}^{3} \mathrm{~cm}^{-3}$ ) during the experimental seasons. 
Day after greening (d)

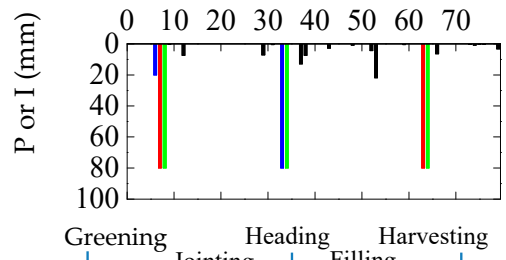

(a) $\mathrm{T} 1$

(b) T2

(d) $\mathrm{T} 4$

(e) $\mathrm{T} 5$
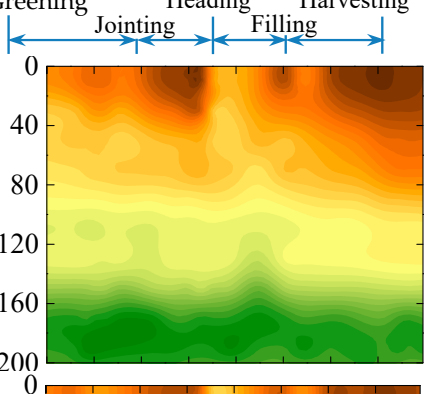

(c) $\mathrm{T} 3 \frac{\text { हृ }}{\text { द्ञ }} 1$
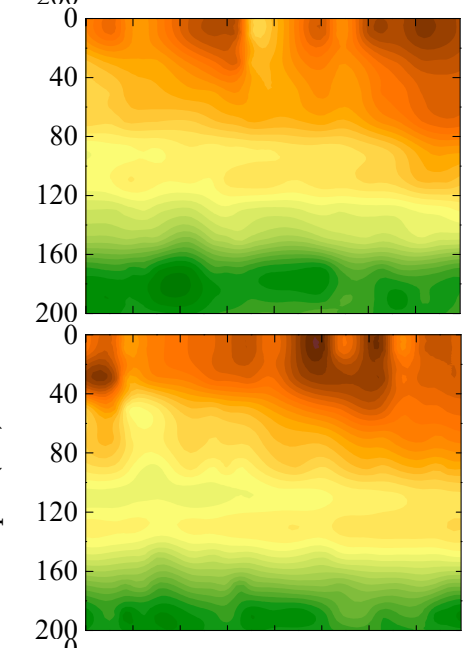

$40-$

$80-$
$120-$

160
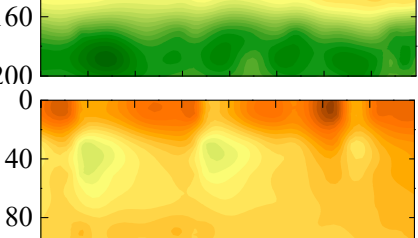

80

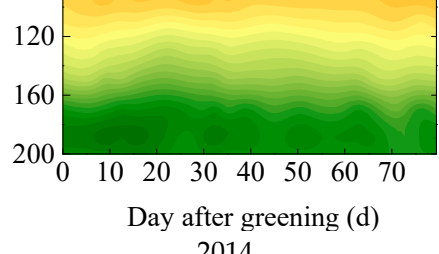

2014
Day after greening (d)
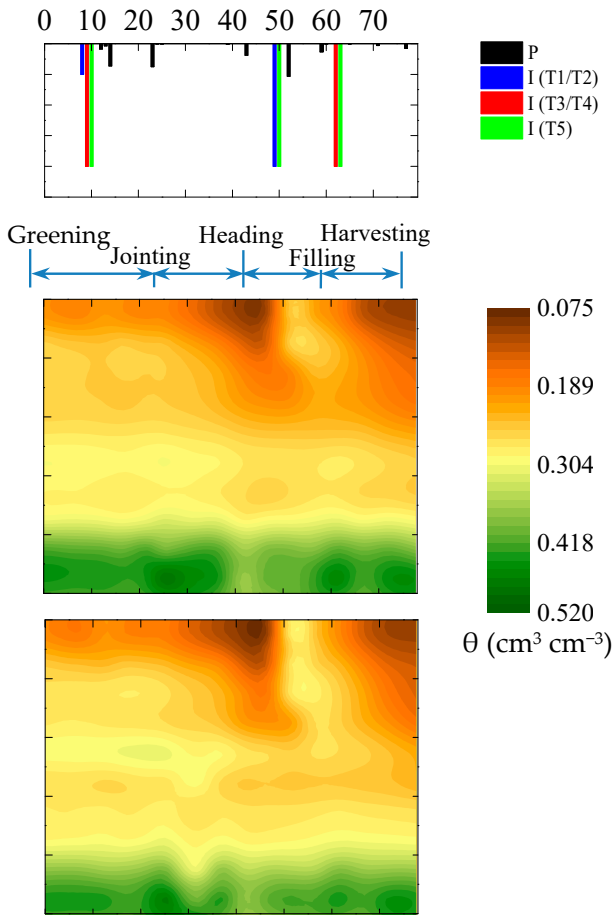

$\theta\left(\mathrm{cm}^{3} \mathrm{~cm}^{-3}\right)$
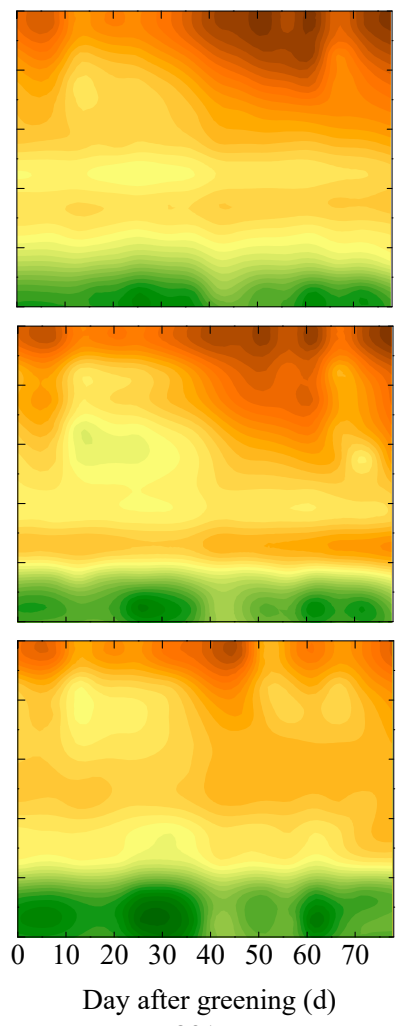

2015

Figure 3. Seasonal variations in the soil moisture under the (a) T1, (b) T2, (c) T3, (d) T4, and (e) T5 treatments.

Significant variations in soil moisture occurred at the rapid development stage of winter wheat (such as the jointing-heading stage) among treatments and seasons, due to the differences in strong evaporation rate, precipitation, and irrigation application (Figure 3). Soil water content varied in a wide range in the $0-20 \mathrm{~cm}$ layer (from 0.11 to $0.23 \mathrm{~cm}^{3} \mathrm{~cm}^{-3}$ with SD of $0.07 \mathrm{~cm}^{3} \mathrm{~cm}^{-3}$ ) and 
20-70 cm layer (from 0.19 to $0.26 \mathrm{~cm}^{3} \mathrm{~cm}^{-3}$ with SD of $0.04 \mathrm{~cm}^{3} \mathrm{~cm}^{-3}$ ) under the T1 treatment with an irrigation application of $80 \mathrm{~mm}$ at the jointing-heading stage in 2014. A similar changing trend of soil water content also appeared under the T2 treatment (ranging from 0.13 to $0.24 \mathrm{~cm}^{3} \mathrm{~cm}^{-3}$ and 0.19 to $0.23 \mathrm{~cm}^{3} \mathrm{~cm}^{-3}$ in the $0-20 \mathrm{~cm}$ and $20-70 \mathrm{~cm}$ layer, respectively). Nevertheless, there was little change in the soil water content under the T3 and T4 treatments without irrigation application at this stage (mean of $0.16 \mathrm{~cm}^{3} \mathrm{~cm}^{-3}$ with SD of $0.02 \mathrm{~cm}^{3} \mathrm{~cm}^{-3}$ in the $0-20 \mathrm{~cm}$ layer and mean of $0.22 \mathrm{~cm}^{3} \mathrm{~cm}^{-3}$ with SD of $0.01 \mathrm{~cm}^{3} \mathrm{~cm}^{-3}$ in the $20-70 \mathrm{~cm}$ layer). Since irrigations (total amount of $160 \mathrm{~mm}$ ) were applied twice before the heading stage under the T5 treatment, soil water content varied in a relatively high range at the jointing-heading stage in $2014\left(0.15-0.24 \mathrm{~cm}^{3} \mathrm{~cm}^{-3}\right.$ and $0.25-0.30 \mathrm{~cm}^{3} \mathrm{~cm}^{-3}$ in the 0-20 cm and 20-70 cm layers, respectively). Therefore, the soil water storage changed distinctly among different treatments at the jointing-heading stage in $2014(-58.4,-26.1,27.5,45.9$, and $-9.4 \mathrm{~mm}$ for the $\mathrm{T} 1, \mathrm{~T} 2, \mathrm{~T} 3, \mathrm{~T} 4$, and $\mathrm{T} 5$, respectively).

Reduction of soil water storage was more significant (mean of $98.1 \mathrm{~mm}$ ) at the jointing-heading stage in 2015 compared to that in 2014, due to much drier climate and non-irrigation application for all treatments at this stage in 2015. Soil water content decreased from 0.18 to $0.11,0.25$ to 0.19 , 0.28 to 0.26 , and 0.40 to $0.34 \mathrm{~cm}^{3} \mathrm{~cm}^{-3}$ in the $0-20 \mathrm{~cm}, 20-70 \mathrm{~cm}, 70-150 \mathrm{~cm}$, and 150-200 cm layers at the jointing-heading stage in 2015 , respectively. Notable soil water storage was depleted in deep layers, accounting for $53.6 \%$ of the total reduction in the soil profile at this stage in 2015 . The soil water storage consumption at the jointing-heading stage accounted for $67.4 \%$ of the total loss in the 2015 growing season. Once soil water near the surface was replenished by irrigation $(80 \mathrm{~mm})$ at the heading-filling stage in 2015, soil water content in the top layer $(0-20 \mathrm{~cm})$ increased remarkably by, on average, $0.15 \mathrm{~cm}^{3} \mathrm{~cm}^{-3}$ under the $\mathrm{T} 1, \mathrm{~T} 2$, and $\mathrm{T} 5$ treatments, respectively. The total reduction of soil water storage was $35.2 \mathrm{~mm}$ more in the 2015 season with respect to that in the 2014 season.

\subsection{Isotopic Compositions of Different Waters}

Isotopes in precipitation were more enriched in the 2015 growing season $(-12.7 \%$ o to $4.9 \%$ o for $\delta^{18} \mathrm{O}$ and $-90.9 \%$ to $25.3 \%$ for $\left.\delta \mathrm{D}\right)$ than those in the 2014 growing season $(-13.3 \%$ to $0.5 \%$ for $\delta^{18} \mathrm{O}$ and $-92.5 \%$ to $8.3 \%$ for $\delta \mathrm{D}$ ), as shown in Figure 4. The local meteoric water line (LMWL) was determined as $\delta \mathrm{D}=7.3 \delta^{18} \mathrm{O}+3.6\left(R^{2}=0.97, p<0.01\right)$ and $\delta \mathrm{D}=6.7 \delta^{18} \mathrm{O}+1.8\left(R^{2}=0.97, p<0.01\right)$ for the 2014 and 2015 seasons, respectively. The smaller slope of LMWL in 2015 was ascribed to the faster evaporation rate of falling raindrops.

(a) $\mathrm{T} 1$
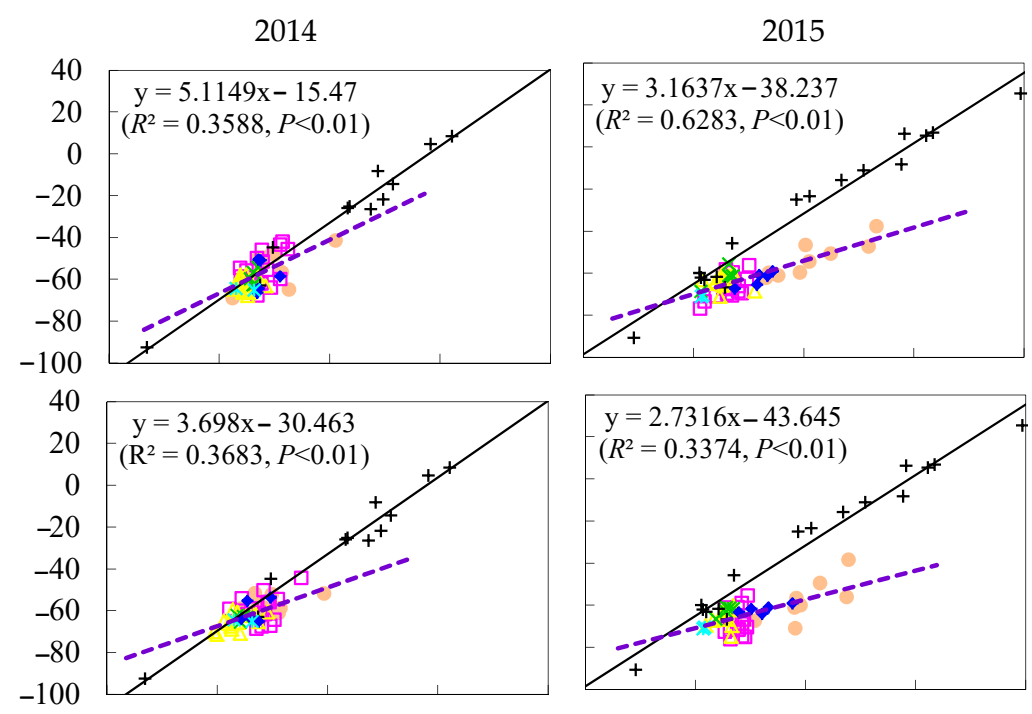

Figure 4. Cont. 
(c) T3
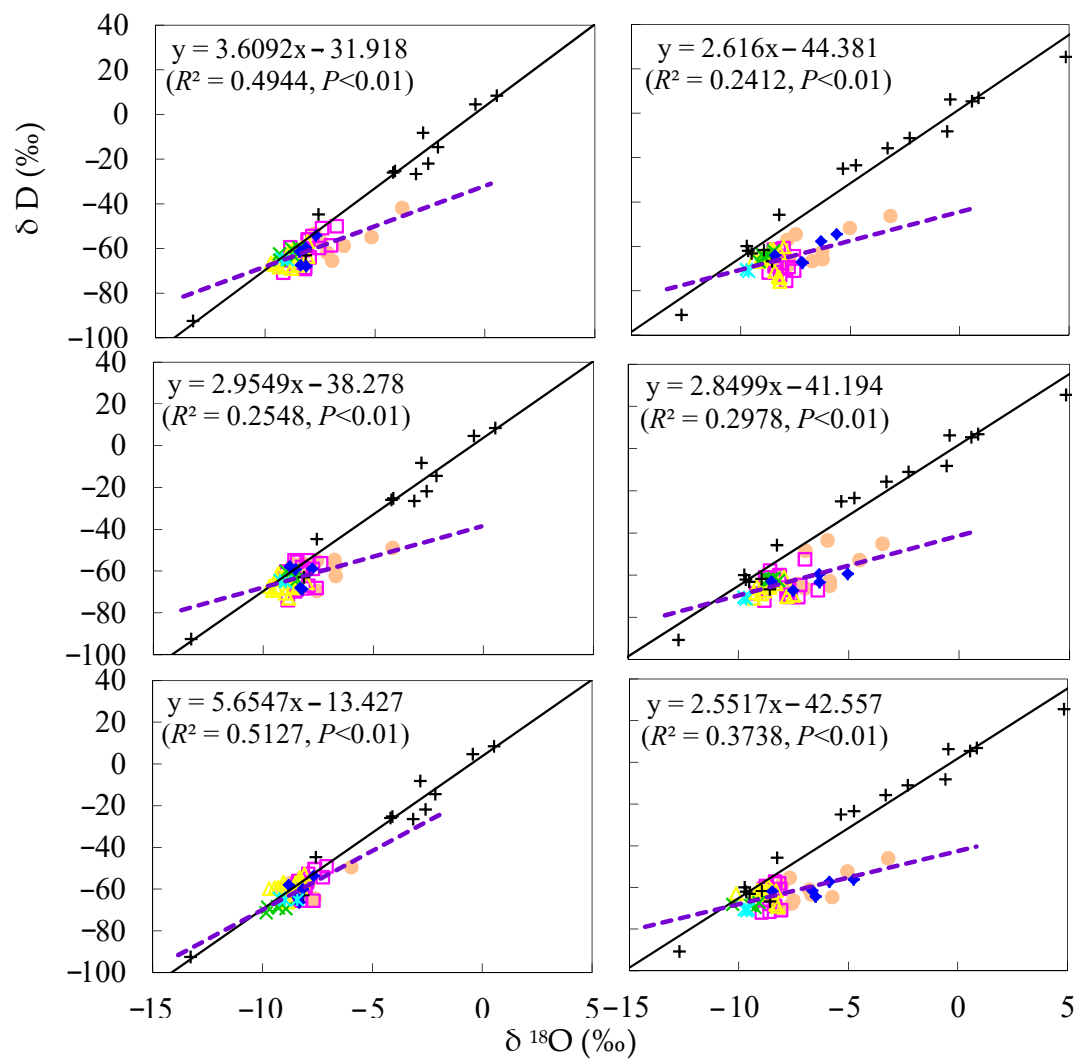

(d) $\mathrm{T} 4$

(e) T5
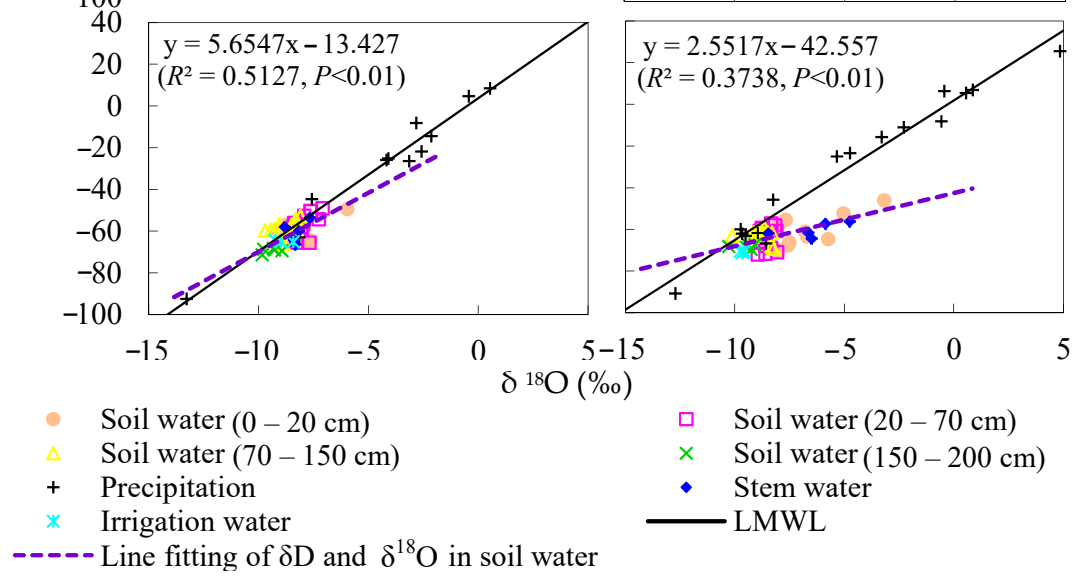
․ Soil water $(20-70 \mathrm{~cm})$
$\times \quad$ Soil water $(150-200 \mathrm{~cm})$
- Stem water
$\longrightarrow$ LMWL

Figure 4. $\delta \mathrm{D}-\delta^{18} \mathrm{O}$ relationship for the water samples under treatment: (a) T1, (b) T2, (c) T3, (d) T4, and (e) $\mathrm{T} 5$ in the 2014 and 2015 growing seasons.

The majority of soil water isotopes for all treatments fell below the LMWL, particularly in 2015 (Figure 4). The slopes of line fitting of $\delta \mathrm{D}$ and $\delta^{18} \mathrm{O}$ in soil water for all treatments were lower with a mean of 2.8 and standard deviation (SD) of 0.2 in 2015, with respect to that in 2014 (mean of 4.2 and SD of 1.1). Remarkable enrichment of heavy isotopes occurred in the top layer $(0-20 \mathrm{~cm})$ and varied significantly throughout the 2015 season due to strong evaporation (Figure 4). Meanwhile, the isotopic composition in the topsoil water changed rapidly with precipitation and irrigation supply in 2015. Isotopic values of soil water in the 150 to $200 \mathrm{~cm}$ layer were uniform with an average of $-63.5 \%$ for $\delta \mathrm{D}$ and $-8.8 \%$ for $\delta^{18} \mathrm{O}$ over two seasons. These values were generally similar to those of irrigation water (mean of $-67.9 \%$ for $\delta \mathrm{D}$ and $-9.3 \%$ for $\delta^{18} \mathrm{O}$ ). However, soil water isotopes in the $150-200 \mathrm{~cm}$ layer were more depleted than irrigation water isotopes under treatment T5 in 2014, which indicated that the heavy rainfall with extremely light isotopes percolated into this layer. Soil water in the $150-200 \mathrm{~cm}$ layer was evaporated evidently with more enriched isotopes than irrigation water under treatments T1, T2, T3, and T4 in 2015 (Figure 4).

The values of $\delta \mathrm{D}$ and $\delta^{18} \mathrm{O}$ in stem water for all treatments were in average of $-61.4 \%$ (SD of $4.7 \%$ ) and $-7.5 \%$ (SD of $1.0 \%$ ), respectively. They mainly concentrated along the fitting line of the $\delta \mathrm{D}-\delta^{18} \mathrm{O}$ relationship in soil water (Figure 4). The majority of the stem water isotopes in 2014 distributed evenly within the soil water isotopes in the $0-150 \mathrm{~cm}$ layer; nevertheless, they were more enriched in 2015 and fell in the $0-70 \mathrm{~cm}$ layer. More stem water isotopes matched with soil water isotopes in the 0-20 cm layer under the T4 and T5 than the other treatments in 2015. These results indicated very distinct water uptake depths of winter wheat among different treatments between the two growing seasons (Figure 4). 


\subsection{Seasonal Variations in the Main RWU Depth}

The main RWU depth of winter wheat in each growing season was evaluated preliminarily using the direct inference method. Both the $\delta \mathrm{D}$ and $\delta^{18} \mathrm{O}$ in soil water matched those in stem water primarily at depths of 0-20 cm, 20-70 cm, 70-150 cm, and 70-150 cm during greening-jointing, jointing-heading, heading-filling, and filling-harvest stages in the 2014 season, respectively (Figure 5). The main RWU depth increased gradually with crop development until the harvest of winter wheat. However, crops predominantly took up soil water from shallow depths of 0-20 cm, 20-70 cm, 0-20 cm, and 20-70 cm during the above four growth stages in the 2015 season (Figure 6). Seasonal variations in the main RWU depth were considerably different among treatments, particularly at the jointing-heading stage in 2015 during which the T1, T2, and T3 had much deeper water uptake depth $(70-200 \mathrm{~cm})$ than that $(0-70 \mathrm{~cm})$ under the T4 and T5 (Figure 6).

(a) T1

Greening-Jointing Jointing-Heading Heading-Filling

Filling-Harvest $\delta \mathrm{D}(\%)$

$-100-80-60-40-20-100-80-60-40-20-100-80-60-40-20$

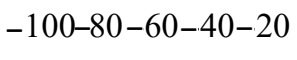

(b) T2
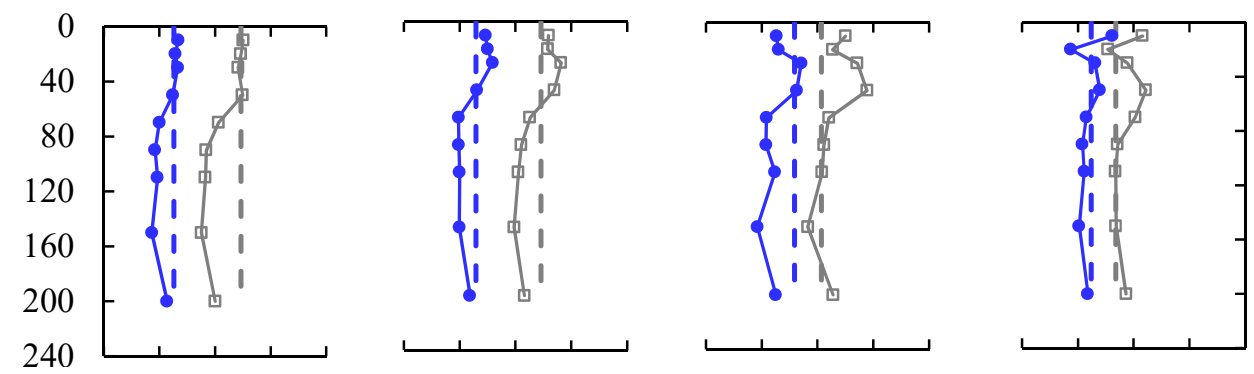

(c) $\mathrm{T} 3$
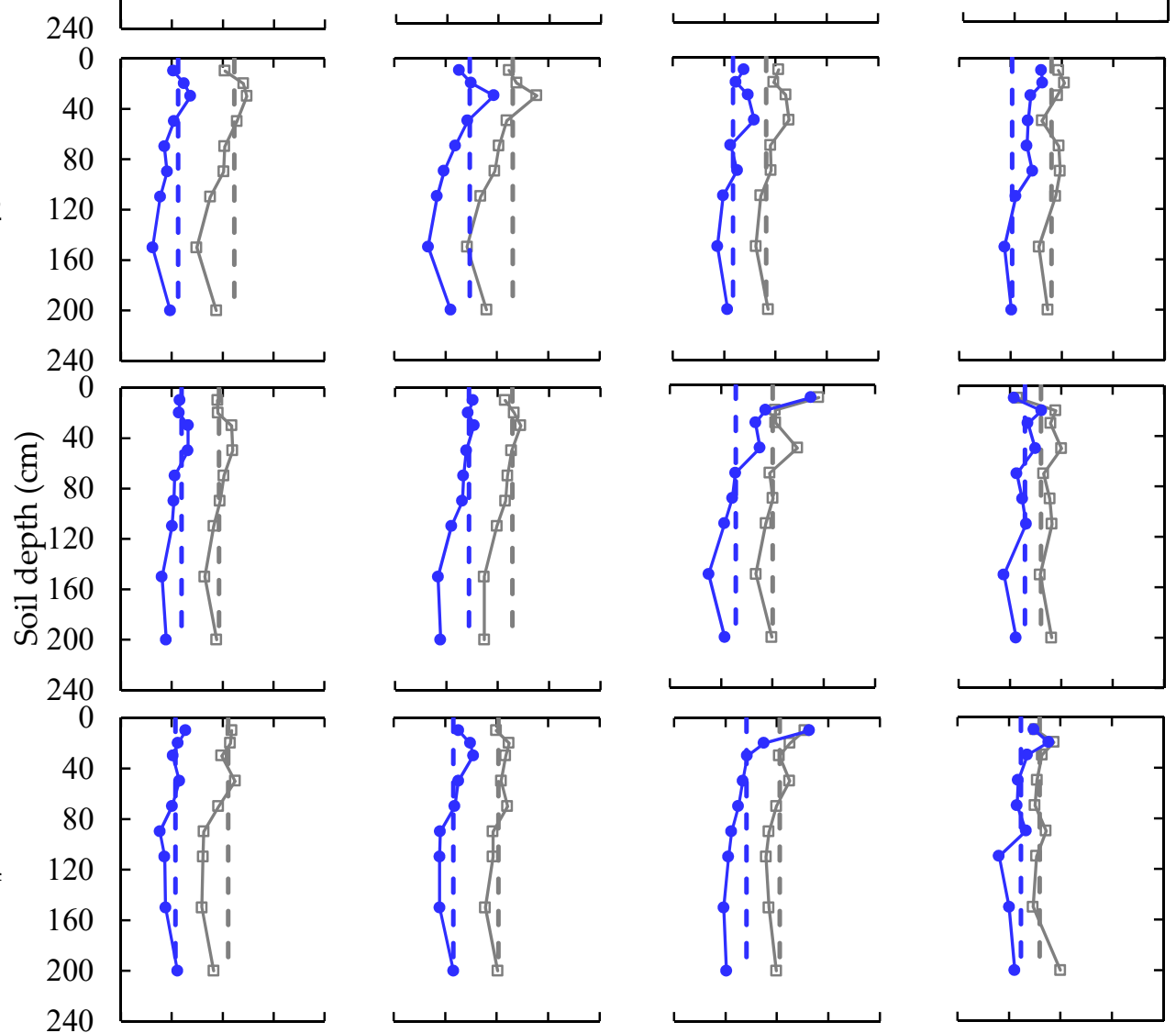

240

Figure 5. Cont. 
(e) T5

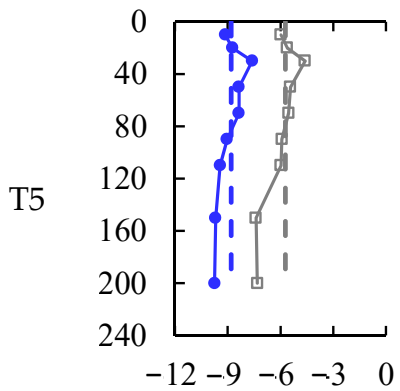

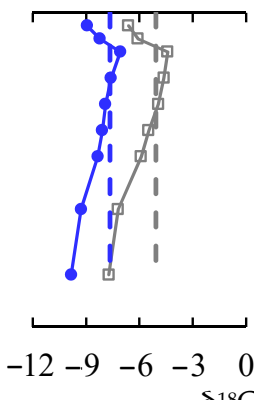

$$
\delta^{18} \mathrm{O}(\%)
$$$$
\square \text { Soil water }(\delta \mathrm{D}) \quad--- \text { Stem water }(\delta \mathrm{D}) \quad \longrightarrow \text { Soil water }\left(\delta^{18} \mathrm{O}\right) \quad--- \text { Stem water }\left(\delta^{18} \mathrm{O}\right)
$$

Figure 5. $\delta \mathrm{D}$ and $\delta^{18} \mathrm{O}$ in soil water and stem water at each growth stage of winter wheat in the 2014 season for treatment: (a) T1, (b) T2, (c) T3, (d) T4, and (e) T5.

Greening-Jointing Jointing-Heading Heading-Filling Filling-Harvest $\delta \mathrm{D}(\%)$

(a) T1 $-100-80-60-40-20-100-80-60-40-20-100-80-60-40-20-100-80-60-40-20$

(b) T2
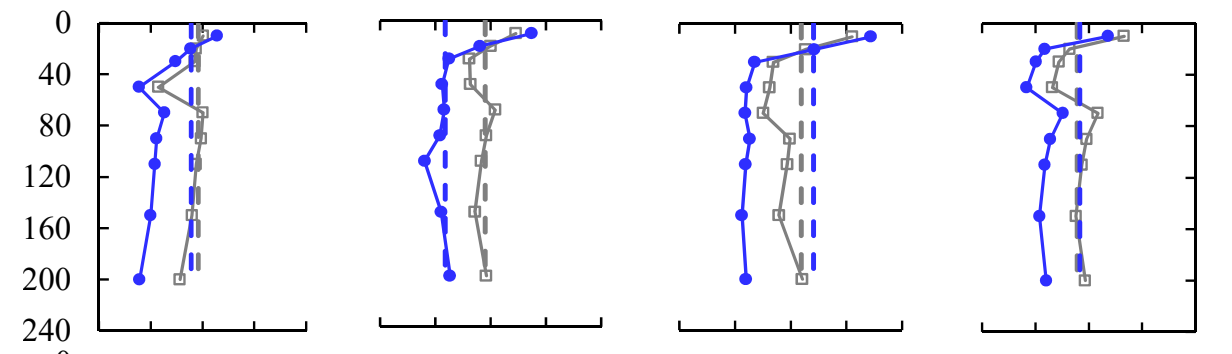

(c) $\mathrm{T} 3$
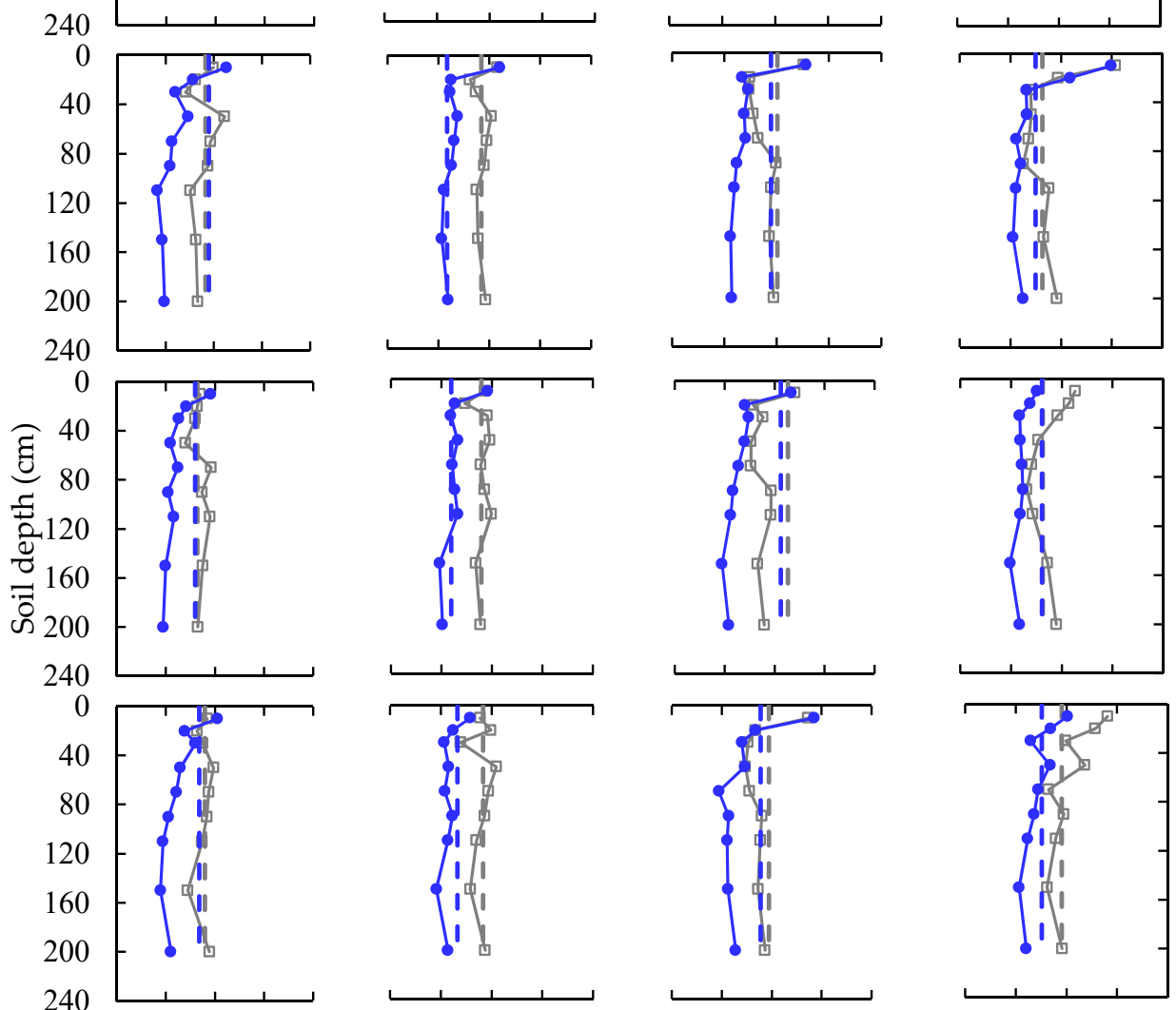

Figure 6. Cont. 
(e) $\mathrm{T} 5$

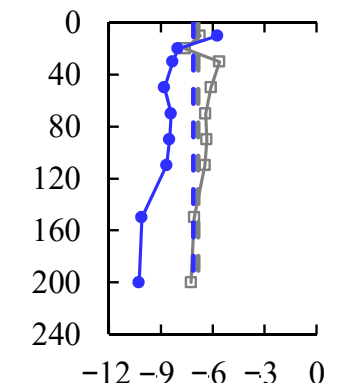

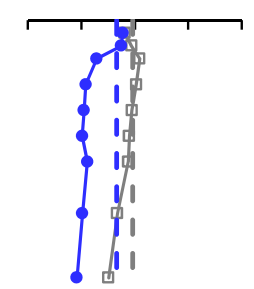

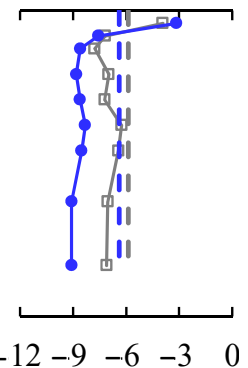

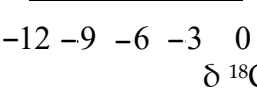

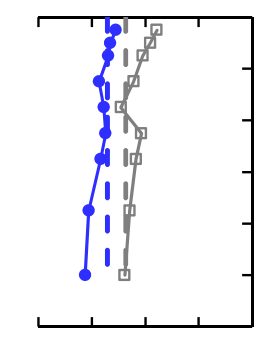

$\begin{array}{lllll}-12 & -9 & -6 & -3 & 0\end{array}$

$$
\longrightarrow \text { Soil water }(\delta \mathrm{D}) \quad---\operatorname{Stem} \text { water }(\delta \mathrm{D}) \quad \longrightarrow \text { Soil water }\left(\delta^{18} \mathrm{O}\right) \quad-- \text { Stem water }\left(\delta^{18} \mathrm{O}\right)
$$

Figure 6. $\delta \mathrm{D}$ and $\delta^{18} \mathrm{O}$ in soil water and stem water at each growth stage of winter wheat in the 2015 season for treatment: (a) T1, (b) T2, (c) T3, (d) T4, and (e) T5.

As is evident from Figures 5 and 6, two identical matching depths inferred by $\delta^{18} \mathrm{O}$ and $\delta \mathrm{D}$ are usually observed under certain treatments in both seasons. However, absolutely different water uptake depths were inferred by dual water stable isotopes in several cases. For instance, the main water uptake depths were determined to be $0-20 \mathrm{~cm}$ and $20-70 \mathrm{~cm}$ from observation of $\delta^{18} \mathrm{O}$, whereas the depths were $70-150 \mathrm{~cm}$ and $150-200 \mathrm{~cm}$ indicated by $\delta \mathrm{D}$ for the T2 treatment at the jointing-heading stage in the 2014 season (Figure 5). There were two distinctly different water uptake depths deduced by $\delta^{18} \mathrm{O}$ and $\delta \mathrm{D}$ under the T1 treatment at the heading-filling stage in 2014 , i.e., $20-70 \mathrm{~cm}$ vs. $70-150 \mathrm{~cm}$. Therefore, it was uncertain and hardly to explicitly specify the main RWU depth under these conditions using the direct inference method.

\subsection{Seasonal Variations in Water Uptake Proportions}

The MixSIAR model was used to quantify the proportional contribution of soil water at different depths to winter wheat. The main water uptake depth was determined as the one with the maximum water uptake proportions. During the 2014 and 2015 seasons, the average contribution of soil water in the $0-20,20-70,70-150$, and $150-200 \mathrm{~cm}$ layers was $35.6 \%, 27.6 \%, 23.1 \%$, and $13.7 \%$, respectively. The primary RWU depth with the contribution of soil water was 0-20 cm $(67.0 \%), 20-70 \mathrm{~cm}(42.0 \%)$, 0-20 cm (38.7\%), and 20-70 cm (34.9\%) during the greening-jointing, jointing-heading, heading-filling, and filling-harvest stages in the two experimental seasons, respectively.

There were significant differences in water uptake patterns during different growth stages in the 2014 and 2015 seasons, as shown in Figure 7. The main water uptake depth gradually increased from $0-20 \mathrm{~cm}(63.6 \%)$ at the greening-jointing stage and $20-70 \mathrm{~cm}(67.9 \%)$ at the jointing-heading stage to $70-150 \mathrm{~cm}$ during the heading-filling stage (54.4\%) and filling-harvest stage (39.8\%) in 2014 (Figure 7). The proportional soil water contribution was remarkably higher in the 0-20 cm layer in $2015(42.6 \%)$ than that in 2014 (28.7\%). Winter wheat primarily took up soil water from the 0-70 cm layer $(75.7 \%)$ in 2015, except at the jointing-heading stage. Deep soil water contribution was promoted significantly $(p<0.01)$ in the layers of $70-150 \mathrm{~cm}(32.2 \%)$ and $150-200 \mathrm{~cm}(23.5 \%)$ at the jointing-heading stage in 2015 (Figure 7). 


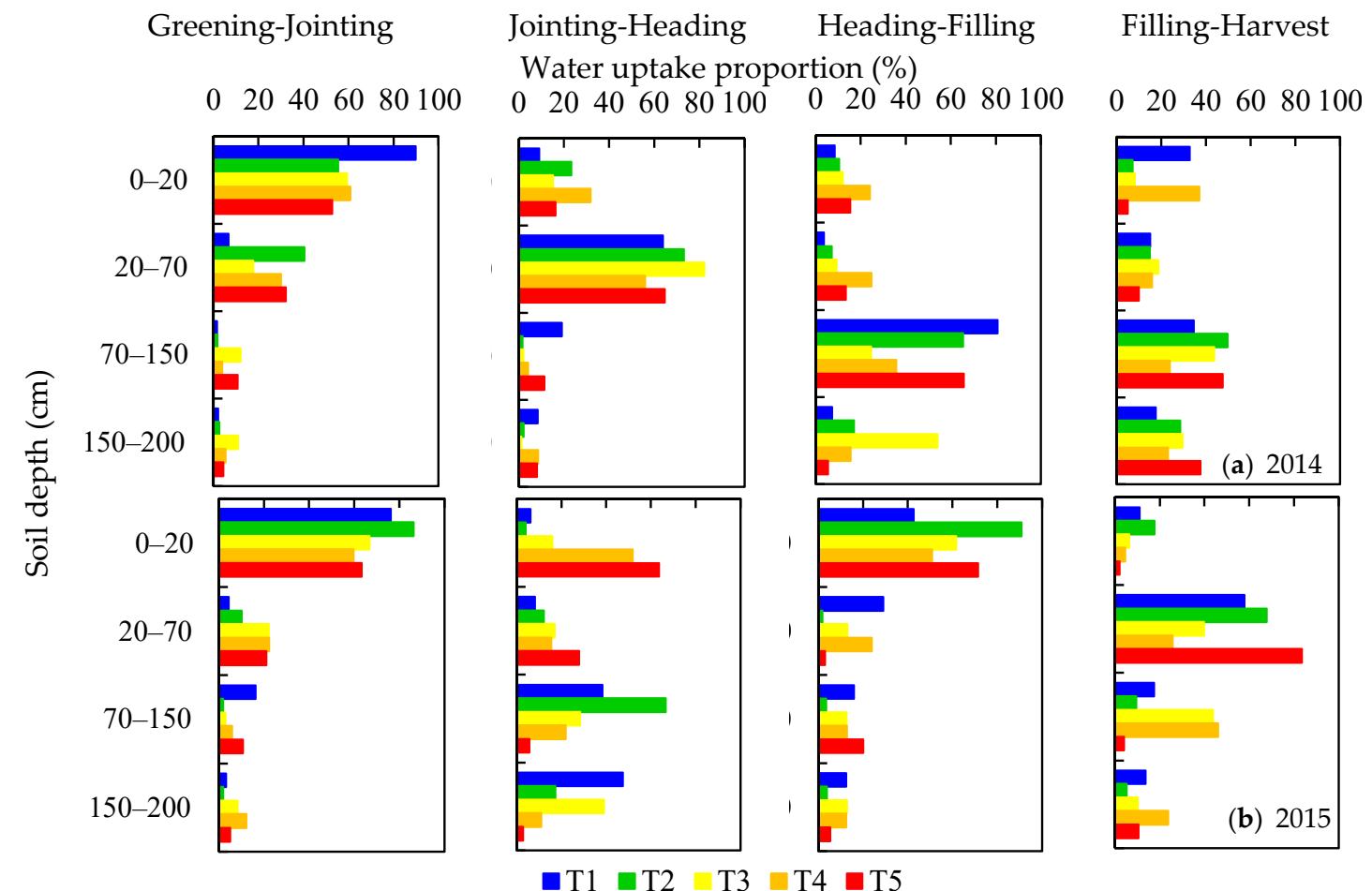

Figure 7. Distributions of water uptake proportions for winter wheat under different treatments at each growth stage in the (a) 2014 and (b) 2015 seasons.

The RWU patterns varied significantly among different irrigation and fertilization treatments in the 2014 and 2015 seasons (Figure 7). The main water uptake depth under the low fertilization treatment T3 $\left(150 \mathrm{~kg} \mathrm{ha}^{-1} \mathrm{~N}\right)$ was deeper $(150-200 \mathrm{~cm})$ with a significant increase of soil water contribution (38.9\%) at the jointing-heading stage in 2015 than that in $2014(20-70 \mathrm{~cm})$ (Figure 7). The largest soil water contribution in the layer of 70-150 (66.6\%) and 150-200 cm (47.3\%) occurred under the T2 and T1 at the jointing-heading stage in 2015, respectively. This was due to a severe water deficit in shallow soil layers caused by dry climate and the reduction of irrigation $(80 \mathrm{~mm})$. In addition, the evapotranspiration rate increased evidently due to the rapid growth of winter wheat at the jointing-heading stage. However, drought environment resulted in significant increase of soil water contribution in the top layer under the T4 (51.8\%) and T5 (63.6\%) at the jointing-heading stage in 2015 , which was supplied with sufficient irrigation $(80 \mathrm{~mm})$ and $210 \mathrm{~kg} \mathrm{ha}^{-1} \mathrm{~N}$ fertilization at the greening-heading stage.

\section{Discussion}

\subsection{Relationship of Root and Soil Moisture Distribution with Water Uptake Patterns}

Root distribution in the soil profile is an important factor in the availability of water to crops [31,32]. Winter wheat had a prolific root system and most roots were concentrated in the $0-40 \mathrm{~cm}$ soil layer. Several studies reported that soil water contribution was correlated positively with the proportion of root length and dry root weight density $[5,13,20]$, while others indicated that the root distribution might not represent the water uptake ability [21,33]. In this study, there was a significantly negative relationship $(p<0.01)$ between the water uptake proportion and the proportion of root length for all treatments in the 2014 season (Figure 8). This may be attributed to the fact that root hydraulic conductivity was lower with shrinkage of roots in the top layer, and fine and young roots in the deep layer were particularly active and thus could access soil water [21]. However, no significant correlation $(p>0.05)$ was found in the 2015 season (Figure 8). The distinct results in 2014 and 2015 seasons indicated that the actual RWU profile was affected by a combination of the root's ability to 
extract water (characterized by the number of roots and their hydraulic properties) and the ability of the soil to fulfill the plant water demand [22].

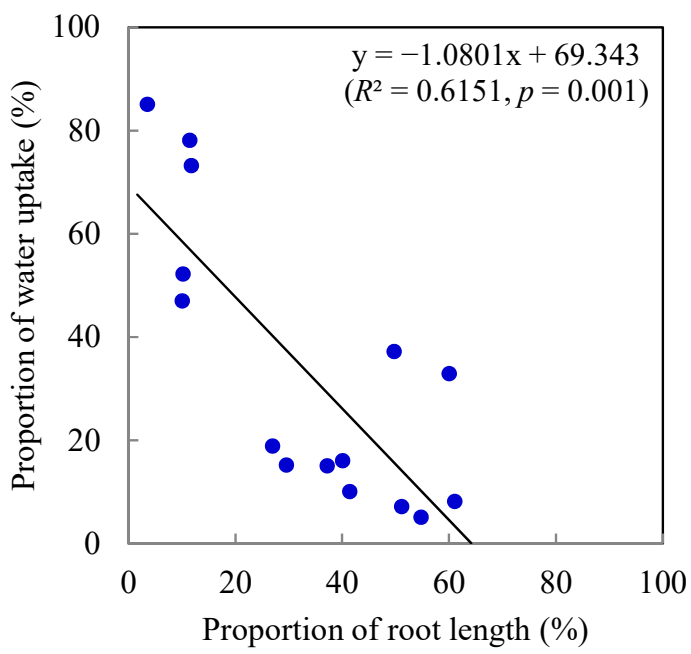

(a) 2014

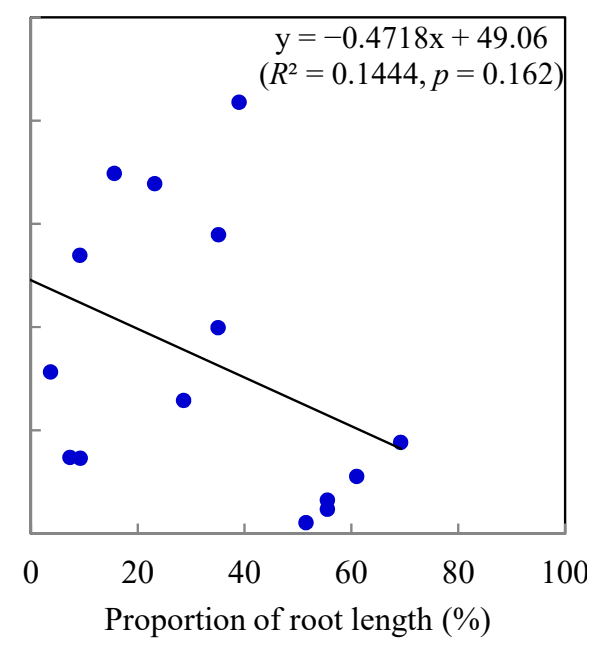

(b) 2015

Figure 8. Relationship between the water uptake proportions and proportions of root length in the (a) 2014 and (b) 2015 seasons.

The RWU pattern was closely correlated with the soil moisture change [34]. The soil water consumption in the $0-150 \mathrm{~cm}$ layer accounted for approximately $92 \%$ of the total soil moisture change for all treatments in wheat greening to harvest season. This agreed well with the average soil water contribution of $86.3 \%$ within the $0-150 \mathrm{~cm}$ layer. Nonsignificant change in the soil water content within the 150-200 cm layer confirmed the relatively small contribution of soil water to root water uptake (mean of $13.7 \%$ with SD of $12.7 \%$ ) (Figures 3 and 7 ). The reduction in soil water storage was significantly more at the jointing-heading stage in 2015 , so that thinner roots took up 55.7\% of soil water from the deep layer of 70-150 cm. The RWU compensation occurred during this dry growth period, when crop extracted water from non- or less-water limited deep soil layers with low root length densities [34]. When soil water near the surface was replenished by irrigation, the extraction depth returned to the surface layer (such as at the heading-filling stage in 2015) and subsequently moved downward again until the harvest of winter wheat [5].

A negative relationship between water uptake proportion and soil volumetric water content was reported in a previous study [20]. Significant negative relationships $(p<0.01)$ were also shown at the greening-jointing and jointing-heading stages in 2014 as well as the greening-jointing and heading-filling stages in 2015 in our study (Figure 9). These results implied that RWU depended on the availability of soil moisture and could result in soil drying at the above growth stages. However, there was no significant relationship $(p>0.05)$ between RWU and soil water content at other growth stages especially at the jointing-heading stage in 2015 (Figure 9). The reason might be that fertilization affected RWU ability under severe drought stress. Moreover, the plant could use active and passive osmotic potential in roots and increase its ability to extract water from dry soil [23]. It can be found that crops primarily utilized soil water from deep layers only at those stages when RWU had a nonsignificant correlation with the soil water content (Figure 9). Therefore, although the initial soil moisture in the deep layers in 2014 differed gently with that in 2015, it was not the dominant factor leading to the differences in RWU patterns between the two growing seasons. 


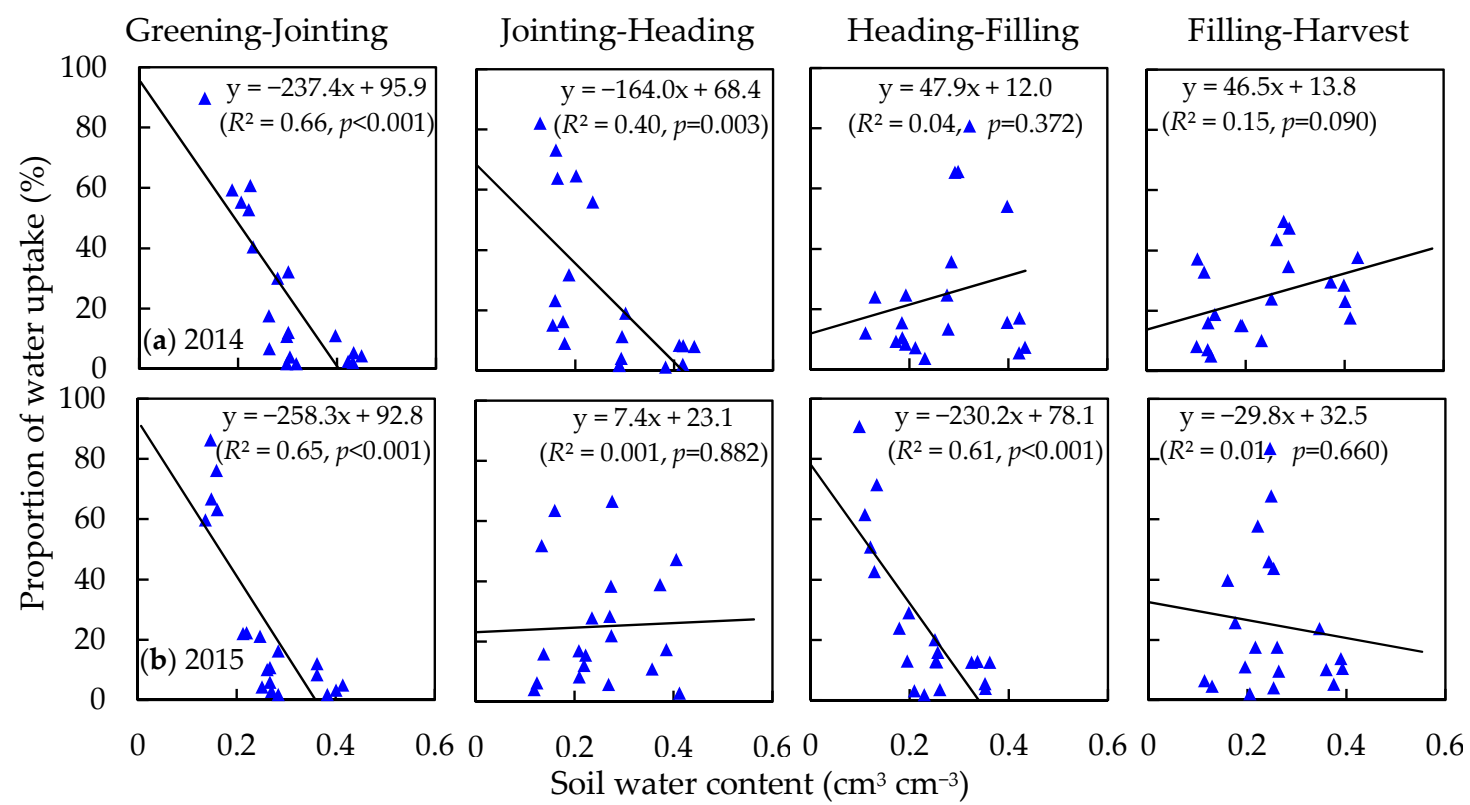

Figure 9. Relationship between water uptake proportion and mean soil water content at each growth stage in the (a) 2014 and (b) 2015 seasons.

\subsection{Effects of Irrigation and Fertilization on Water Uptake Patterns}

The main RWU depth has been previously reported to be $0-40 \mathrm{~cm}$ under conventional irrigation practice in normal years $[3,20]$. However, different irrigation and fertilization treatments resulted in considerable differences in the root water uptake patterns of winter wheat, especially at the developing growth stage under dry conditions in this study (Figure 7). Frequent irrigation has been reported to produce plenty of roots near the soil surface [3]. This led to a main water uptake depth of $0-20 \mathrm{~cm}$ under the T5 treatment at the jointing-heading stage in 2015. The total soil water contribution reached $91.4 \%$ in the $0-70 \mathrm{~cm}$ layer. Soil water content along the profile also showed the smallest variability (mean of $0.02 \mathrm{~cm}^{3} \mathrm{~cm}^{-3}$ ) under the T5 treatment.

High nitrogen concentration in the top layer could increase the drought resistance of the root system when water supply was limited $[35,36]$. Although the main water uptake depth was $0-20 \mathrm{~cm}$ under the T4 treatment, soil water in the $70-150 \mathrm{~cm}$ layer contributed $21.9 \%$ to winter wheat due to excessive percolation of nitrogen into deep layers. Among the five treatments, T4 had the highest consumption of soil water storage $(174.5 \mathrm{~mm})$ during the 2015 season. Nevertheless, nitrogen deficiency under the T1 and T3 treatments stimulated RWU ability and promoted soil water contribution by $43.1 \%$ in the deep layer of $150-200 \mathrm{~cm}$. Previous studies demonstrated that plants growing in drier environments with water deficit in the surface layer have deeper root systems and more branched seminal roots $[4,5]$. They were able to extract a significant proportion of water from the deep soil layers [37]. This proved that over $80 \%$ of plant water sourced from soil water in the $70-200 \mathrm{~cm}$ layer under $\mathrm{T} 1$ and $\mathrm{T} 2$ treatments with less irrigation.

\subsection{Implications for Agricultural Management Practices}

Irrigation is necessary because there is a large gap between crop water requirement and precipitation amount. Matching the irrigation wetting layer with the main RWU depth could alleviate the water scarcity and avoid nitrogen percolation into groundwater $[3,13]$. In this study, the main water uptake depth indicated that irrigation should be controlled in the $0-20 \mathrm{~cm}$ and $20-70 \mathrm{~cm}$ layer at the greening-jointing and jointing-heading stages in 2014; respectively, whereas the wetting layer was better in the 0-20 cm layer at both the greening-jointing and heading-filling stages in 2015. Irrigation was unnecessary at the filling-harvest stage as deep thin roots were more active to take up water from deep soil layers in both seasons. Therefore, the planned wetting layer should be within a depth 
of $0-70 \mathrm{~cm}$ because wheat primarily sourced soil water from the $0-70 \mathrm{~cm}$ layer for all treatments in dry years. This proper irrigation depth was slightly deeper than that in the normal years $(0-40 \mathrm{~cm})$ reported in previous studies $[3,20]$. This practice could make better use of deep soil water storage and avoid deep percolation compared with the traditional wetting depth of $100 \mathrm{~cm}$.

Small irrigation $(20 \mathrm{~mm})$ at the vegetative stage of winter wheat could reduce water loss due to soil evaporation and nonfunctional tillers for improving grain yield [38]. The antecedent soil moisture in deep layers was adequate for winter wheat to utilize due to great recharge by heavy rainfalls in the previous summer maize season. It was evident that no irrigation and low fertilization at the jointing-heading stage increased the ability of drought resistance and soil water use in the root zone. High utilization of available soil water was generally linked to high crop production $[5,39]$. After experiencing severe drought stress, an irrigation of $80 \mathrm{~mm}$ recovered at the heading-filling stage was stored dominantly in the $0-70 \mathrm{~cm}$ layers (Figure 3). The heading growth stage was extremely sensitive to water stresses, and irrigation was strongly recommended during this period $[27,28]$. These agreements between irrigation supply and crop water utilization occurred under the T1 treatment in the 2015 season. The irrigation water use efficiency (the ratio of crop yield and irrigation water amount) was at its maximum $\left(71.0 \mathrm{~kg} \mathrm{ha}^{-1} \mathrm{~mm}^{-1}\right)$ under the $\mathrm{T} 1$ treatment in 2015 and improved by $21.4 \%$ relative to the mean value of the five treatments. Therefore, $20 \mathrm{~mm}$ and $80 \mathrm{~mm}$ of irrigation water during the greening-jointing and heading-filling stages, and $105 \mathrm{~kg} \mathrm{ha}^{-1} \mathrm{~N}$ of fertilization during the greening-jointing stage were appropriate for agricultural management. This recommended irrigation and fertilization scheduling could reduce $140 \mathrm{~mm}$ of irrigation water and $105 \mathrm{~kg} \mathrm{ha}^{-1} \mathrm{~N}$ of fertilizer with respect to the conventional practices.

\subsection{Scope for Further Research Arising from this Study}

The evaluation using isotopic data presented a quantitative interpretation of crop water use from various soil layers and determined the seasonal variations of RWU patterns. This method explicitly contributed to the field water cycle, and provided insights into exploring optimal water and fertilization management practices. Nevertheless, several issues still need further investigations. First, besides quantifying the proportional contributions of soil water to vegetation and determining the RWU pattern, the isotope-based methods can be extended to partition ET (i.e., the ratio of E and T). The results obtained by the isotope-based models should be compared with the soil water balance models such as SIMDualKc [40] and SWAT [41]. Second, soil moisture is a critical factor of crop growth and transformation of water and energy in the soil-crop system. Actual ET and RWU are not just influenced by soil water content, and vegetation response may deviate from ordinary responses after a drought period [23]. Therefore, the detailed responses of RWU to soil moisture variation and their feedbacks need further investigation, which is very useful for the determination of water-energy balance and optimal irrigation mode [42]. Finally, the RWU pattern was influenced by the relative evolution of the rooting system over time. In this study, the root distribution was measured only at the filling-harvest stage. The root distribution at different stages should be measured or simulated by the optimality-based model [43] in order to determine the dynamic relationships between root distribution and RWU pattern over the growing season.

\section{Conclusions}

The MixSIAR model coupled with dual water stable isotopes was used to determine seasonal variations in RWU patterns of winter wheat under different irrigation and fertilization treatments during 2014-2015 in Beijing, China. The average contribution of soil water in the 0-20, 20-70, $70-150 \mathrm{~cm}$, and $150-200 \mathrm{~cm}$ layers was $35.6 \%, 27.6 \%, 23.1 \%$, and $13.7 \%$ during the experimental seasons, respectively. The main water uptake depth was 0-20, 20-70, 0-20 cm, and 20-70 cm at greening-jointing, jointing-heading, heading-filling, and filling-harvest stages, respectively. A significant difference in crop water sources at different stages appeared between two growing seasons. The main water uptake depth gradually increased from the $0-20 \mathrm{~cm}$ layer at the greening-jointing stage to $20-70 \mathrm{~cm}$ at the 
jointing-heading stage and $70-150 \mathrm{~cm}$ during the heading to harvest period in 2014. Nevertheless, winter wheat took up soil water mainly from the shallow layer of $0-70 \mathrm{~cm}$ in 2015 , except that significant soil water contribution $(p<0.01)$ in the layers of $70-150 \mathrm{~cm}(32.2 \%)$ and $150-200 \mathrm{~cm}(23.5 \%)$ at the jointing-heading stage was promoted under extreme drought stress without precipitation and irrigation. The main RWU depths under small irrigation or low nitrate fertilization treatments were remarkably deeper $(70-200 \mathrm{~cm})$ than that $(0-20 \mathrm{~cm})$ under abundant irrigation and fertilization treatments at the jointing-heading stage in 2015. There was a significantly negative relationship $(p<0.01)$ between water uptake proportions and proportions of the root length for all treatments at the filling-harvest stage in 2014, but no significant correlation $(p>0.05)$ was found in 2015. Soil water availability and root length distribution comprehensively determined the RWU patterns under water-limited conditions. The irrigation wetting layer was better to match the main water uptake depth and designed within 0-70 cm for winter wheat in the study area. This study provides a simple and effective method for quantifying RWU. The findings are of great significance for future fertilization and irrigation management in agricultural ecosystems.

Author Contributions: Y.M. conducted the data analysis and was responsible for the idea of the study and writing of the manuscript and X.S. provided important advice on the methodology.

Funding: This research was funded by the National Natural Science Foundation of China, grant No 41671027 and 41730749 .

Acknowledgments: The authors are grateful for the support of B.Z. and L.Y. in the field experiments. We offer our sincere thanks to N.S. and J.D. for collecting field data. We thank the three anonymous reviewers for their constructive comments that improved the quality of this manuscript.

Conflicts of Interest: The authors declare no conflicts of interest.

\section{References}

1. Fan, Y.; Miguez-Macho, G.; Jobbagy, E.G.; Jackson, R.B.; Otero-Casal, C. Hydrologic regulation of plant rooting depth. Proc. Natl. Acad. Sci. USA 2017, 114, 10572-10577. [CrossRef] [PubMed]

2. Jasechko, S.; Sharp, Z.D.; Gibson, J.J.; Birks, S.J; Yi, Y.; Fawcett, P.J. Terrestrial water fluxes dominated by transpiration. Nature 2013, 496, 347-350. [CrossRef] [PubMed]

3. Zhang, Y.C.; Shen, Y.J.; Sun, H.Y.; Gates, J.B. Evapotranspiration and its partitioning in an irrigated winter wheat field: A combined isotopic and micrometeorologic approach. J. Hydrol. 2011, 408, 203-211. [CrossRef]

4. Jha, S.K.; Gao, Y.; Liu, H.; Huang, Z.D.; Wang, G.S.; Liang, Y.P.; Duan, A.W. Root development and water uptake in winter wheat under different irrigation methods and scheduling for North China. Agric. Water Manag. 2017, 182, 139-150. [CrossRef]

5. Zhang, X.Y.; Pei, D.; Chen, S.Y. Root growth and soil water utilization of winter wheat in the North China Plain. Hydrol. Process. 2004, 18, 2275-2287. [CrossRef]

6. Mahindawansha, A.; Orlowski, N.; Kraft, P.; Rothfuss, Y.; Racela, H.; Breuer, L. Quantification of plant water uptake by water stable isotopes in rice paddy systems. Plant Soil 2018, 429, 281-302. [CrossRef]

7. Rothfuss, Y.; Javaux, M. Reviews and syntheses: Isotopic approaches to quantify root water uptake: A review and comparison of methods. Biogeosciences 2017, 14, 2199-2224. [CrossRef]

8. Zimmermann, U.; Ehhalt, D.; Munnich, K. Soil water movement and evapotranspiration: Changes in the isotopic composition of the water. In Proceedings of the IAEA Symposium on the Use of Isotopes in Hydrology, Vienna, Austria, 14-18 November 1966; pp. 567-585.

9. Phillips, D.L.; Gregg, J.W. Source partitioning using stable isotopes: Coping with too many sources. Oecologia 2003, 136, 261-269. [CrossRef] [PubMed]

10. McCole, A.A.; Stern, L.A. Seasonal water use patterns of Juniperus ashei on the Edwards plateau, Texas, based on stable isotopes in water. J. Hydrol. 2007, 342, 238-248. [CrossRef]

11. Moore, J.W.; Semmens, B.X. Incorporating uncertainty and prior information into stable isotope mixing models. Ecol. Lett. 2008, 11, 470-480. [CrossRef] [PubMed]

12. Stock, B.C.; Semmens, B.X. MixSIAR GUI User Manual, version 1.0; 2013. Available online: http://conserver. iugo-cafe.org/user/brice.semmens/MixSIAR (accessed on 12 November 2018). 
13. Ma, Y.; Song, X.F. Using stable isotopes to determine seasonal variations in water uptake of summer maize under different fertilization treatments. Sci. Total Environ. 2016, 550, 471-483. [CrossRef] [PubMed]

14. Yang, B.; Wang, P.Y.; You, D.B.; Liu, W.J. Coupling evapotranspiration partitioning with root water uptake to identify the water consumption characteristics of winter wheat: A case study in the North China Plain. Agric. For. Meteorol. 2018, 259, 296-304. [CrossRef]

15. Wang, J.; Fu, B.J.; Lu, N.; Zhang, L. Seasonal variation in water uptake patterns of three plant species based on stable isotopes in the semi-arid Loess Plateau. Sci. Total Environ. 2017, 609, 27-37. [CrossRef] [PubMed]

16. Leroux, X.; Bariac, T.; Mariotti, A. Spatial partitioning of the soil water resource between grass and shrub components in a west African humid savanna. Oecologia 1995, 104, 147-155. [CrossRef] [PubMed]

17. Schwendenmann, L.; Pendall, E.; Sanchez-Bragado, R.; Kunert, N.; Hölscher, D. Tree water uptake in a tropical plantation varying in tree diversity: Interspecific differences, seasonal shifts and complementarity. Ecohydrology 2015, 8, 1-12. [CrossRef]

18. Huang, L.; Zhang, Z.S. Stable isotopic analysis on water utilization of two xerophytic shrubs in a revegetated desert area: Tengger Desert, China. Water 2015, 7, 1030-1045. [CrossRef]

19. Asbjornsen, H.; Mora, G.; Helmers, M.J. Variation in water uptake dynamics among contrasting agricultural and native plant communities in the Midwestern US. Agric. Ecosyst. Environ. 2007, 121, 343-356. [CrossRef]

20. Zhao, X.; Li, F.D.; Ai, Z.P.; Li, J.; Gu, C.K. Stable isotope evidences for identifying crop water uptake in a typical winter wheat-summer maize rotation field in the North China Plain. Sci. Total Environ. 2018, 618, 121-131. [CrossRef] [PubMed]

21. Nosalewicz, A.; Lipiec, J. The effect of compacted soil layers on vertical root distribution and water uptake by wheat. Plan Soil 2014, 375, 229-240. [CrossRef]

22. Couvreur, V.; Vanderborght, J.; Draye, X.; Javaux, M. Dynamic aspects of soil water availability for isohydric plants: Focus on root hydraulic resistances. Water Resour. Res. 2014, 50, 8891-8906. [CrossRef]

23. Sofo, A.S.; Manfreda, S.; Fiorentino, M.; Dichio, B.; Xiloyannis, C. The olive tree: A paradigm for drought tolerance in Mediterranean climates. Hydrol. Earth Syst. Sci. 2008, 12, 293-301. [CrossRef]

24. Guo, X.H.; Sun, X.H.; Ma, J.J.; Lei, T.; Zheng, L.J.; Wang, P. Simulation of the water dynamics and root water uptake of winter wheat in irrigation at different soil depths. Water 2018, 10, 1033. [CrossRef]

25. Javaux, M.; Couvreur, V.; Vander Borght, J.; Vereecken, H. Root water uptake: From three-dimensional biophysical processes to macroscopic modeling approaches. Vadose Zone J. 2013, 12. [CrossRef]

26. Cai, J.B.; Liu, Y.; Xu, D.; Paredes, P.; Pereira, L.S. Simulation of the soil water balance of wheat using daily weather forecast messages to estimate the reference evapotranspiration. Hydrol. Earth Syst. Sci. 2009, 13, 1045-1059. [CrossRef]

27. Li, J.M.; Inanaga, S.; Li, Z.H.; Eneji, A.E. Optimizing irrigation scheduling for winter wheat in the North China Plain. Agric. Water Manag. 2005, 76, 8-23. [CrossRef]

28. Shang, S.H.; Mao, X.M. Application of a simulation based optimization model for winter wheat irrigation scheduling in North China. Agric. Water Manag. 2006, 85, 314-322. [CrossRef]

29. Wang, P.; Song, X.F.; Han, D.M.; Zhang, Y.H.; Liu, X. A study of root water uptake of crops indicated by hydrogen and oxygen stable isotopes: A case in Shanxi Province, China. Agric. Water Manag. 2010, 97, 475-482. [CrossRef]

30. Brunel, J.P.; Walker, G.R.; Dighton, J.C.; Monteny, B. Use of stable isotopes of water to determine the origin of water used by the vegetation and to partition evapotranspiration. A case study from HAPEX-Sahel. J. Hydrol. 1997, 188-189, 466-481. [CrossRef]

31. Rasse, D.P.; Smucker, A. Root recolonization of previous root channels in corn and alfafa rotations. Plant Soil 1998, 204, 203-212. [CrossRef]

32. Li, Q.Q.; Dong, B.D.; Qiao, Y.Z.; Liu, M.Y.; Zhang, J.W. Root growth, available soil water, and water-use efficiency of winter wheat under different irrigation regimes applied at different growth stages in North China. Agric. Water Manag. 2010, 97, 1676-1682. [CrossRef]

33. Flanagan, L.B.; Ehleringer, J.R.; Marshall, J.D. Differential uptake of summer precipitation among co-occurring trees and shrubs in a pinyon-juniper woodland. Plant Cell Environ. 1992, 15, 831-836. [CrossRef]

34. Heinen, M. Compensation in root water uptake models combined with three-dimensional root length density distribution. Vadose Zone J. 2014, 13. [CrossRef]

35. Kmoch, H.G.; Ramig, R.E.; Fox, R.L.; Koehler, F.E. Root development of winter wheat as influenced by soil moisture and nitrogen fertilization. Agron. J. 1957, 49, 20-26. [CrossRef] 
36. Carvalho, P.; Foulkes, M.J. Roots and uptake of water and nutrients. In Sustainable Food Production; Christou, P., Savin, R., Costa-Pierce, B., Misztal, I., Whitelaw, C.B., Eds.; Springer: New York, NY, USA, 2013; pp. 1390-1404.

37. Angadi, S.V.; Entz, M. Root system and water use patterns of different height sunflower cultivars. Agron. J. 2002, 94, 136-145. [CrossRef]

38. Sun, H.Y.; Liu, C.M.; Zhang, X.Y.; Shen, Y.J.; Zhang, Y.Q. Effects of irrigation on water balance, yield and WUE of winter wheat in the North China Plain. Agric. Water Manag. 2006, 85, 211-218. [CrossRef]

39. Hsiao, T.C. Growth and productivity of crops in relation to water status. Acta Hortic. 1993, 335, 137-148. [CrossRef]

40. Paredes, P.; Rodrigues, G.J.; Petry, M.T.; Severo, P.O.; Carlesso, R.; Pereira, L.S. Evapotranspiration partition and crop coefficients of Tifton 85 bermudagrass as affected by frequency of cuttings. Application of the FAO56 dual Kc model. Water 2018, 10, 558. [CrossRef]

41. Singh, G.; Saraswat, D.; Sharpley, A. A sensitivity analysis of impacts of conservation practices on water quality in L'Anguille River Watershed, Arkansas. Water 2018, 10, 443. [CrossRef]

42. Yang, Y.; Huang, Y.; Zhang, Y.; Tong, X. Optimal irrigation mode and spatio-temporal variability characteristics of soil moisture content in different growth stages of winter wheat. Water 2018, 10, 1180. [CrossRef]

43. Schymanski, S.J.; Sivapalan, M.; Roderick, M.L.; Hutley, L.B.; Beringer, J. An optimality-based model of the dynamic feedbacks between natural vegetation and the water balance. Water Resour. Res. 2009, 45, W01412. [CrossRef]

(C) 2018 by the authors. Licensee MDPI, Basel, Switzerland. This article is an open access article distributed under the terms and conditions of the Creative Commons Attribution (CC BY) license (http://creativecommons.org/licenses/by/4.0/). 